Article

\title{
Financing of Entrepreneurial Firms in Canada: Some Patterns
}

\author{
Anton Miglo 1 \\ Department of Accounting, Finance and Economics, Birmingham City University, Birmingham B4 7BD, UK; \\ anton.miglo@bcu.ac.uk
}

Received: 14 June 2020; Accepted: 31 July 2020; Published: 6 August 2020

check for updates

\begin{abstract}
This article analyzes the patterns of financing for entrepreneurial firms in Canada. We compare the predictions of major theories of entrepreneurial finance and some more recent ideas (e.g., crowdfunding-related ideas/theories) with empirical evidence. Regression and correlation analyses were used to analyze the connections between firms' financing choices (e.g., debt/equity ratio) and different variables such as firm age, firm owner origin, and the fraction of intangibles assets. We found strong evidence that the financing choices of entrepreneurial firms in Canada are consistent with flexibility theory and credit rationing theory. We did not find evidence that taxes play a significant role in explaining these choices. We also found that the likelihood of using crowdfunding is consistent with local bias ideas and internet access. We also provide an overview of literature related to entrepreneurial financing in Canada and discuss its major challenges and directions for future research.
\end{abstract}

Keywords: entrepreneurial finance in Canada; small business financing; capital structure; crowdfunding

JEL Classification: F30; G15; G18; G21; G24; G28; G32; G38; M13

\section{Introduction}

In this article, we analyze the patterns of financing for entrepreneurial firms in Canada. Financing is an important and puzzling topic for large corporations (see, for example, a survey of managers by Graham and Harvey in 2001) as well as for entrepreneurial firms (Jõeveer 2013). Several theories that explain the ideas of firm capital structure and financing choice exist, including the flexibility theory of financing innovations, asymmetric information, credit rationing and the life cycle theory (for a review, see, for example, Harris and Raviv 1991; Klein et al. 2002; Miglo 2011). Firstly, most of these theories do not have unanimous empirical support (see, e.g., a discussion in Frank and Goyal 2003). Some of these theories find some support in some countries but not in others (see, e.g., de Jong et al. 2008; Jõeveer 2013) ${ }^{1}$. Secondly, the implications and relative importance of these theories are different for corporations and entrepreneurial firms (see, e.g., Frank and Goyal 2003; Lee et al. 2015). Thirdly, in recent years, some new theories that are focused on entrepreneurial firms (see, e.g., Robb and Robinson 2012) have been offered. Fourthly, debates still continue about which theory is the dominant one in the area of firm financing. For large firms, the trade-off theory and the pecking-order theory have emerged as the most important ones (see, e.g., the debates in Graham and Harvey 2001; Miglo 2016). However, what theories are more important for entrepreneurial firms? Finally, in the last decade or so, some new ways of financing entrepreneurial firms (such as crowdfunding) and several new ideas about these types of financing have been developed. For all these reasons, the topic of financing for entrepreneurial firms remains interesting and important.

1 In general, the topic of capital structure and optimal financing remains one of the most controversial topics in finance (see, e.g., Graham and Harvey 2001). 
Several articles address the capital structure choice by large corporations in Canada (see, e.g., King and Santor 2008; Gill and Mathur 2011). The financing of entrepreneurial firms has been studied in several articles that focus on some specific types of financing (e.g., Cumming and MacIntosh 2003, 2006; Suret 2008 (focused on venture capital finance)). An analysis of the effect of different theories on the financing choices of entrepreneurial firms that takes into account all types of financing, as well as a comparison of theories' relative importance, has not been done. At the same time, Canada is one of the top countries in terms of developing new ways of financing, such as crowdfunding ${ }^{2}$, as well as one of the best countries in terms of entrepreneurial support ${ }^{3}$. In this article, we aim to analyze the implications of the main theories of financing with regard to entrepreneurial firms in Canada.

Below, we briefly describe the main theories of financing and formulate the hypothesis of our research.

Signalling by risk-bearing (Leland and Pyle 1977) predicts that the good quality entrepreneur would keep a higher fraction of shares in his/her company than the low-quality entrepreneur. It assumes that firms have private information about the quality of their projects, and on the other hand, entrepreneurs are risk-averse. By holding a relatively high fraction of equity, the entrepreneur sends a signal to market participants that the firm has good quality projects and that he/she is ready to bear the risk of these projects.

The flexibility theory (Diamond 1991) suggests that if a firm has too much debt or it does not have any credit experience, it will be harder for it to obtain loans when necessary. Firms, therefore, preserve debt capacity or hold back on issuing debt because they want to maintain flexibility. Firms maintain excess debt capacity or larger cash balances than warranted by current needs in order to meet unexpected future requirements. The flexibility theory predicts that firms with a lot of potential investment and growth opportunities should have a lower debt/equity ratio. While maintaining this financing flexibility has value to firms, it also has a cost; the excess debt capacity implies that the firm is giving up some value and has a higher cost of capital.

The credit rationing idea suggests that if an investment yields large returns, the firm's owners capture most of the gains. If, however, the investment fails, debt holders bear the consequences. As a result, the firm's owners may benefit from investing in high-risk projects, even if the projects are value-decreasing. This leads to a decrease in the value of debt and reduces the incentive to provide loans when the investment choice is difficult to monitor, especially in the case of start-up firms. In some cases, it leads to the credit rationing phenomenon (Stiglitz and Weiss 1981) when there is no equilibrium for bank loans, even if a firm has a positive net present value (NPV) project available. The main implication of the credit rationing idea is that banks may refuse to provide a loan if the uncertainty regarding the firm's projects is very high, which is often the case for small or start-up companies.

In contrast to dividends, interest paid on debt reduces the firm's taxable income. Debt also increases the probability of bankruptcy. Trade-off theory suggests that capital structure reflects a trade-off between the tax benefits of debt and the expected costs of bankruptcy (Kraus and Litzenberger 1973). As the expected bankruptcy costs increase, the advantages of using equity also increase. This result has several interpretations. Small firms that are less diversified and have a higher default risk should use less debt. Tangible assets suffer a smaller loss of value when firms go into distress. Hence, firms with more tangible assets should have higher leverage compared to those that have more intangible assets, such as research firms. Growth firms tend to lose more of their value than nongrowth firms when they go into distress. Thus, the theory predicts a negative relationship between leverage and growth. Higher taxes lead to the greater tax advantage of using debt. Hence, firms with higher tax rates should have higher debt ratios compared to firms with lower tax rates. Inversely, firms that have substantial nondebt tax shields, such as depreciation, should be less likely to use debt than firms that do not have these tax shields. If tax rates increase over time, debt ratios should also increase. Debt ratios in countries where debt has a much larger tax benefit should be higher than debt ratios in countries whose debt has a lower tax benefit.

\footnotetext{
https://www.statista.com/outlook/335/108/crowdfunding/Canada.

https://www.cnbc.com/2018/02/05/us-world-news-report-2018-top-10-best-countries-for-entrepreneurs.html.
} 
The life cycle theory of capital structure (e.g., Damodaran 2003) predicts that firms in the development stage will abstain from issuing risky debt and will instead issue equity. Firms in the growth stage will begin generating positive earnings. Accordingly, these firms rely on debt financing to fund their growth options as they face less financing constraints and as they expect to repay their debt with growing future earnings. Thus, firms in the growth stage tend to have high leverage ratios. Firms in the maturity stage generate large cash flows from assets already in place and rely mainly on self-financing for their investment needs. They are more concerned with servicing the debt they raised during the growth stage than they are with issuing more debt because they expect future cash flows to deteriorate. Accordingly, mature firms prefer to maintain moderate debt levels.

In recent years, Canada has been quite successful in developing new forms of financing for entrepreneurial firms, including crowdfunding. This area belongs to FinTech, which refers to innovative technologies used to improve the financial sector (Das 2019). Crowdfunding is a form of fundraising usually performed online, where firms raise funds from a large number of investors/funders (see, e.g., Ahlers et al. 2015). In the literature, it has been suggested that crowdfunding relaxes geographic constraints on fundraising, which inhibit venture capital and angel financing (Agrawal et al. 2010). By volume of these sources of finance, Canada is consistently ranked among the top 10 countries (see, e.g., Huang et al. 2019) ${ }^{4}$. Research in these areas is quickly growing.

The main aim of this paper is to gain new scientific knowledge about the patterns of financing for entrepreneurial firms in Canada. In particular, we will look at different variables describing the financing strategies of these firms (such as the sources of finance used and debt/equity ratios) and connect them with different features of these firms, such as size, age of the owner, and asset structures. The key research question for us is to identify what theory of financing is able to highlight the behaviour of entrepreneurial firms in Canada. Based on the analysis of major theories of financing for entrepreneurial firms described previously, we will analyze the following hypotheses.

Hypothesis 1 (H1). Smaller firms have a lower percentage of approved requests compared to larger firms.

Hypothesis 2 (H2). Entrepreneurs born outside Canada have a lower approval rate.

Hypothesis 3 (H3). Younger firms have a lower approval rate compared to mature firms.

Hypothesis 4 (H4). Firms in knowledge-based industries and industries with a high fraction of intangible assets have lower debt/equity ratios compared to other industries.

Hypothesis 5 (H5). Firms with higher expected bankruptcy costs have lower debt/equity ratios than firms with lower expected bankruptcy costs.

Hypothesis 6 (H6). Firms with higher tax rates have higher debt/equity ratios than firms with lower tax rates.

Hypothesis 7 (H7). Younger firms have lower debt/equity ratios than older firms.

Hypothesis 8 (H8). The likelihood of using crowdfunding is positively correlated with the provincial population.

Hypothesis 9 (H9). The likelihood of using crowdfunding is positively correlated with internet access.

The rest of the paper is organized as follows. Section 2 provides a literature review. Section 3 describes the methodology and data sources. Section 4 describes the results of our analysis. Section 5 provides concluding remarks, discusses the limitations of our analysis, directions for future research, as well as the state of entrepreneurial finance education in Canada. 


\section{Literature Review}

Existing literature on traditional debt and equity financing for entrepreneurial firms in Canada usually focuses on explaining the problems of external financing for entrepreneurial firms or why interest rates on loans are typically higher for small- and medium-sized enterprises (SMEs) than for large firms ${ }^{5}$. For example, Beck et al. (2008) analyzed the financing patterns of firms in 48 countries, including Canada, and found that the ability of smaller cash-constrained firms to obtain external financing, including bank financing, was more limited as compared to larger firms.

Some literature focuses on venture capital financing for entrepreneurial firms. Historically, venture capital financing reached its peak in 2000, and afterwards, its growth rates were not very impressive. One factor behind this pattern was the great recession of 2008/2009. Furthermore, in Canada, the venture capital industry has problems such as relatively low listing requirements. This reduces the incentive for SMEs to partner with venture capital firms on the one hand, and on the other hand, it creates a lot of asymmetric information about SMEs (Carpentier and Suret 2010), which creates difficulties in raising public funds and a reduced interest from venture capital firms. Another interesting aspect of the venture capital industry in Canada is the large presence of labour-sponsored funds (LSVCF) ${ }^{6}$. Historically they played an important role in the creation of the venture capital industry, especially in Quebec. However, it seems like their institutional structure needs some major revisions in order to move the venture capital industry forward (Cumming and MacIntosh 2003, 2006; Cumming et al. 2007; Lerner 2009; MacIntosh 2012; Suret 2008). There have been some improvements in the venture capital industry during the last 10 years. The government implemented a venture capital support program in 2013 that included deploying CAD400 million in new capital over the next 7 to 10 years to reinvigorate the venture capital sector in Canada ${ }^{7}$. As a result, we observed a sharp increase (2014/2015) in the amounts of venture financing. Additionally, the growth of angel financing and accelerators is observed in most OCDE countries, including Canada.

Crowdfunding is a new way of financing for entrepreneurial firms that has become very popular around the world, including in Canada, in the last 10 years or so. It is a highly growing area of interest among practitioners and theorists (see, e.g., Ahlstrom et al. 2018). As we write this article, the number of empirical papers significantly exceeds the number of theoretical papers. Rainey et al. (2017) discussed major types of crowdfunding and their growth before focusing on equity crowdfunding as a method of financing for small businesses and start-ups in light of the recent legislative changes related to equity crowdfunding in both the United States (US) and Canada. The authors covered the current global market and both countries' new legislation, as well as the specific challenges and benefits of equity crowdfunding. They also touched on what the new trends in crowdfunding could mean for impact investing, with a spotlight on the millennial generation's investing patterns ${ }^{8}$.

For large companies, the implications of different theories of financing and capital structure have been analyzed, for example, by Gill and Mathur (2011). In this article, we aim to analyze the implications of the main theories of financing with regard to entrepreneurial firms.

We seek to make several conceptual and empirical contributions. Firstly, we hope to make an important contribution to our knowledge about the theories of financing and capital structure choice theories (Harris and Raviv 1991; Cumming et al. 2019). This topic remains controversial and puzzling for large companies (Graham and Harvey 2001) as well as for entrepreneurial firms (Bhaumik et al. 2015). Secondly, we would like to help fill the research gap related to the patterns of

5 The interest rate on loans to SMEs is, on average, 4 percentage points higher than the rate charged to large firms (https://www.oecd.org/cfe/smes/SME-Scoreboard-2016-Highlights.pdf).

6 For a history of LSVCF and their major features see, for example, Vaiiancourt (1998).

7 We use traditional notations for currencies (see, for example, https://ca.finance.yahoo.com/currencies/investing.html): CAD for Canadian dollars, USD for American dollars.

8 A more detailed description of different sources of financing available for entrepreneurial firms in Canada is present in Appendix A. 
financing of entrepreneurial firms in Canada. Many previous studies have focused on some specific types of finance for these firms (e.g., private equity (Cumming et al. 2007)) but not on a systematic analysis of these patterns. Thirdly, this article contributes to the growing line of research in finance and entrepreneurship that uses surveys (see, e.g., Jude and Adamou 2018). The survey provided by Statistics Canada is quite unique and should help researchers with a lot of data about entrepreneurial firms' access to finance, which, in many countries, is quite limited (Schmidt et al. 2017). Finally, this paper contributes to the entrepreneurship literature in general. The reason is that, as many studies argue and many surveys, including surveys we use, confirm, the financial activities of entrepreneurial firms are the key problem for the majority of these firms. For many of them, it is the key reason for failure. The problem of entrepreneurial firms is that they do not have a large number of assets, nor do they have a long credit history or liquid market for their shares. As a result, they do not have easy access to external sources of capital. Obviously, they do not generate a lot of profits, especially in the initial stages of their development, so the internal sources of financing for them are also limited. In these conditions, it is vital for these firms to understand the major theoretical ideas of financing, as well as the knowledge of how these ideas interact practically with available data in order to be as efficient as possible when dealing with different sources of financing and to increase the chances of their survival. In this regard, we also look at student education related to entrepreneurial finance in Canada. The quality of this education is crucial for developing entrepreneurial finance and, ultimately, for developing entrepreneurship in Canada (for similar ideas, see, e.g., Solesvik et al. 2014).

\section{Methodology}

We mostly use two sources of data. Firstly, we use OCDE data that compares entrepreneurial finance in Canada with other OCDE members ${ }^{9}$. Secondly, we use the Statistics Canada/Industry Canada data about the financial needs of small- and medium-sized businesses because most entrepreneurial businesses are found in this group ${ }^{10}$. Thus, we will use information about the financing of small- and medium-sized enterprises (SMEs) as a proxy for the financing experience of entrepreneurial businesses ${ }^{11}$.

Regression analysis (the ordinary least square model) and correlation analysis will be the methods used to determine the strength of the relationship between firm financing choices and other variables.

For example, to test $\mathrm{H} 3$, the formula for regression is

$$
\text { Debt/equity ratio }=\alpha+\beta_{1} \times \mathrm{ICT}+\beta_{2} \times \mathrm{RD}+\beta_{3} \times \mathrm{New}+\beta_{4} \times \mathrm{C}+\varepsilon,
$$

where the dependent variable is the debt/equity ratio. The independent variables are the fraction of the firm's total assets invested in communication and technology (ICT), research and development (RD) and new machinery (New), and the control variables (C) include different variables such as firm sales.

To test $\mathrm{H7}$, the formula for regression is

Number of crowdfunding providers $=\alpha+\beta_{1} \times$ Population $+\beta_{2} \times \mathrm{GDP} /$ capita $+\beta_{3} \times$ Market income/capita $+\beta_{4} \times \mathrm{HC}+\beta_{5} \times \mathrm{HI}+\beta_{6} \times$ Entrepren $+\varepsilon$,

where the dependent variable is the number of crowdfunding providers in a province. The independent variables include provincial population (Population), GDP per capita (GDP/capita), market income per capita (Market income/capita), the number of households with a computer at home (HC), the number of households with access to the internet (HI) and a variable (Entrepren) that measures the level of provincial support for entrepreneurship (as a proxy, we used the international ranking of the province's largest city). We normalized data using an approach similar to Beck et al. (2008).

9 http://www.oecd-ilibrary.org/industry-and-services/financing-smes-and-entrepreneurs_23065265;jsessionid= a4qc4i6hdobm3.x-oecd-live-02.

10 Throughout this article, if the source of data is not explicitly indicated, then it is one of the two sources indicated above.

11 Industry Canada defines small- and medium-sized enterprises as those with fewer than 500 employees. http://www.ic.gc.ca/ eic/site/061.nsf/eng/Home. 
In some cases where the available data were limited, comparison or qualitative methods were used.

\section{Patterns of Financing for Entrepreneurial Firms in Canada}

The main implication of the credit rationing idea (Stiglitz and Weiss 1981) is that banks may refuse to provide a loan if the uncertainty regarding the firm's projects is very high, which is often the case for small or start-up companies. Typically, banks and other potential investors have more information about large companies.

This table shows the amounts of requested and approved debt financing of different types by Canadian SMEs in 2013. In most cases (as follows from lines 2-6 of Table 1), smaller firms had a lower percentage of approved requests compared to larger firms. Similarly, firms in knowledge-based industries also had a lower approval rate (75.5\%) compared to the SME average (86.1\%). Additionally, younger firms had a lower approval rate than older firms (see section "Age of Business"), and entrepreneurs born outside Canada had a lower approval rate (see section "Place of birth"). It is reasonable to assume that in all these cases, banks have less information regarding the category of firms with lower approval rates than the category(ies) with higher approval rates. This provides strong support for our Hypotheses H1-H3.

Table 1. Canadian small- and medium-sized enterprises (SMEs) debt financing.

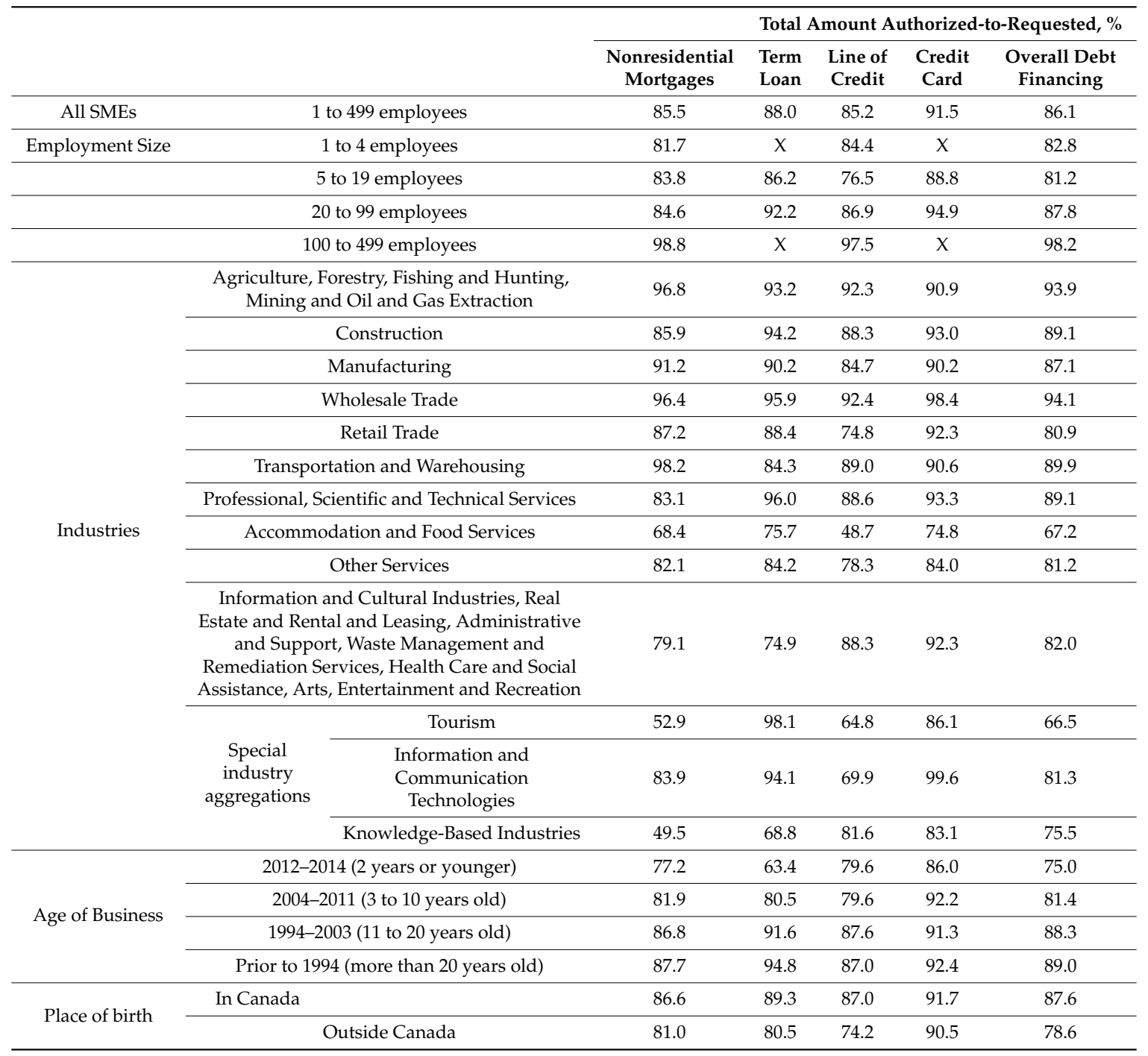

Source: IndustryCanada/Statistics Canada, Survey on Financing and Growth of Small and Medium Enterprises, 2014. 
These patterns of financing of Canadian SMEs are consistent with patterns in many other countries. For example, in the Euro area, access to finance and finance conditions appear to be consistently more favourable for large enterprises than for SMEs, with a smaller percentage of large firms reporting supply restrictions in the provision of bank loans, consistently higher rates of success and lower rejection rates and a considerably lower net percentage of large firms reporting an increase in interest rates and collateral requirements (See e.g., Hashi and Toçi 2010; OECD 2012).

Signalling by risk-bearing (Leland and Pyle 1977) predicts that the good-quality entrepreneur would keep a higher fraction of shares in his/her company than the low-quality entrepreneur. One can see an implication of the signalling idea in some cases discussed in Appendix A. For example, it is often the case for government funding or different grants for entrepreneurial firms: it often requires the owner to keep a significant fraction of the firm's equity or to make additional investments in the firm's equity. It can be used as a signal of an entrepreneurial idea's quality. For example, one of the requirements of the microvoucher program in Alberta is that the entrepreneur provides $25 \%$ of financing using his/her own funds in order to obtain government financing for research and development investments (Table A2).

The flexibility theory suggests that firms maintain excess debt capacity or larger cash balances than warranted by current needs in order to meet unexpected future requirements.

Tables 2 and 3 demonstrate that firms that invest in RD, new machinery and ICT (i.e., firms with uncertain growth) have a smaller fraction of $\mathrm{debt}^{12}$. Additionally, the debt/assets ratio in knowledge-based industries, which by their nature require a lot of flexibility, is significantly below the average ratio among all SMEs, and, in fact, knowledge-based industries have one of the lowest ratios among all industries ${ }^{13}$. This analysis provides strong support for $\mathrm{H} 4$.

Table 2. Capital structure of SMEs in different industries.

\begin{tabular}{|c|c|c|c|c|c|}
\hline & & R\&D/Assets & $\begin{array}{c}\text { (R\&D + ICT }{ }^{*}+ \\
\text { New Machine + } \\
\text { Edu)/Assets }\end{array}$ & $\begin{array}{c}\text { (ICT + New } \\
\text { Machine + } \\
\text { Edu)/Assets }\end{array}$ & $\begin{array}{c}\text { Total Debt } \\
\text { Provided/(Total Debt } \\
\text { + Total Equity) }\end{array}$ \\
\hline All SMEs & & 0.101423 & 0.185788 & 0.084365 & 0.876402 \\
\hline \multirow{11}{*}{ Industries } & $\begin{array}{l}\text { Agriculture, Forestry, Fishing and } \\
\text { Hunting, Mining and Oil and } \\
\text { Gas Extraction }\end{array}$ & 0.030194 & 0.09795 & 0.067756 & 0.851103 \\
\hline & Construction & 0.024912 & 0.103518 & 0.078606 & 0.879258 \\
\hline & Manufacturing & 0.107341 & 0.187031 & 0.07969 & 0.914535 \\
\hline & Wholesale Trade & 0.078696 & 0.155541 & 0.076845 & 0.932882 \\
\hline & Retail Trade & 0.019579 & 0.144089 & 0.12451 & 0.954592 \\
\hline & Transportation and Warehousing & 0.069976 & 0.31067 & 0.240694 & 0.820551 \\
\hline & $\begin{array}{l}\text { Professional, Scientific and } \\
\text { Technical Services }\end{array}$ & 0.358487 & 0.447588 & 0.089101 & 0.839725 \\
\hline & Accommodation and Food Services & NA & NA & 0.0661 & 0.948222 \\
\hline & Other Services & NA & NA & 0.034778 & 0.636527 \\
\hline & $\begin{array}{l}\text { Health Care and Social Assistance, } \\
\text { Information and Cultural Industries, } \\
\text { Arts, Entertainment and Recreation }\end{array}$ & 0.054745 & 0.121457 & 0.066712 & 0.736784 \\
\hline & Knowledge-Based Industries & 0.255537 & 0.344665 & 0.089128 & 0.668598 \\
\hline
\end{tabular}

Sources: Statistics Canada, Survey on Financing and Growth of Small and Medium Enterprises 2011.

${ }^{*}$ ICT-investments in communications and technology.

12 See Baldwin and Johnson (1996) for an example of a comparison of innovative firms and other firms based on large list of criteria.

13 The calculations are present for 2011. They are very similar for 2014. 
Table 3. Regression results. The dependent variable is the total debt provided/total liabilities (2011) ratio.

\begin{tabular}{ccccc}
\hline Variables & $\mathbf{( 1 )}$ & $\mathbf{( 2 )}$ & $\mathbf{( 3 )}$ & $\mathbf{( 4 )}$ \\
\hline Intercept & $0.8849(15.0750)^{* * *}$ & $0.8386(21.0297)^{* * *}$ & $0.8348(24.2261)^{* * *}$ & $0.8019(142.2934)^{* * *}$ \\
R\&D & $-0.4138(-1.1011)^{* *}$ & $-0.4138(-1.1011)^{* * *}$ & $-0.7642(-1.9316)^{* * *}$ & $-0.3617(-5.5060)^{* * *}$ \\
ICT & $-5.7091(-2.9636)^{* *}$ & $-5.7091(-2.9636)^{* *}$ & $-3.6529(-1.7157)^{* *}$ & $-6.0310(-16.6178)^{* * *}$ \\
new machine & $-0.5933(-1.1839)^{* *}$ & $-0.5933(-1.1839)^{* * *}$ & $-1.0699(-2.0147)^{* * *}$ & $-1.2679(-16.3216)^{* * *}$ \\
Personnel cost & & $23.8033(2.9661)^{* *}$ & $22.9318(3.3036)^{* *}$ & $30.9827(25.8864)^{* *}$ \\
Sales & & & $0.0339(1.5433)^{*}$ & $0.0441(13.5520)^{*}$ \\
Income & & & & $-0.1426(-12.0323)^{* *}$ \\
Adj. $R^{2}$ & 0.4160 & 0.7718 & 0.8304 & 0.9965 \\
F-value & 2.9002 & 7.7671 & 8.8370 & 384.4273 \\
\hline$* * *$ indicates significance at a 1\% level, ${ }^{* *}$ indicates significance at a 5\% level, and *indicates significance at a \\
10\% level.
\end{tabular}

The trade-off theory suggests that capital structure reflects a trade-off between the tax benefits of debt and the expected costs of bankruptcy (Kraus and Litzenberger 1973).

Expected Bankruptcy Costs and Debt. As the expected bankruptcy costs increase, the advantages of using equity also increase. This result has several interpretations. Large firms should have more debt because they are more diversified and have a lower default risk (see, e.g., Adair and Adaskou 2015). Start-up and small firms should use less debt. Tangible assets suffer a smaller loss of value when firms go into distress. Hence, firms with more tangible assets, such as airplane manufacturers, should have higher leverage compared to those that have more intangible assets, such as research firms (Ozkan 1996). Growth firms tend to lose more of their value than nongrowth firms when they go into distress. Thus, the theory predicts a negative relationship between leverage and growth. Tables 2 and 3 provide some evidence that is consistent with these predictions. Firms with high amounts of intangible assets (and respectively high indirect bankruptcy costs) have smaller debt/equity ratios. This supports the hypothesis $\mathrm{H} 5$.

Taxes and Debt. Higher taxes lead to the greater tax advantage of using debt. Hence, firms with higher tax rates should have higher debt ratios compared to firms with lower tax rates (see, e.g., Modigliani and Miller 1963; Devereux et al. 2017). Inversely, firms that have substantial nondebt tax shields, such as depreciation, should be less likely to use debt than firms that do not have these tax shields. If tax rates increase over time, debt ratios should also increase. Debt ratios in countries where debt has a much larger tax benefit should be higher than debt ratios in countries whose debt has a lower tax benefit. In Canada, the tax rate is lower for small businesses. This implies that there is less incentive to issue debt for tax-saving purposes.

From the above tables, we can see that for small businesses, the tax argument of capital structure does not have a strong confirmation. Otherwise, one should see a positive correlation between the tax rate and the debt ratio. One does not see this relationship when looking at data from different countries and different provinces in Canada. For example, from Table 4, Manitoba has smaller tax rates for small businesses than the Atlantic Provinces, while the debt ratio is lower in Manitoba. The correlation coefficients between debt ratios and small business tax rates are negative in Table 5 . As follows from Table 6, the debt ratio is higher in Korea, for example, than in Canada, while the tax rates for small businesses are lower in Korea. The correlation coefficients are insignificant in Table 7, although it is slightly negative between the small business tax rate (all levels of government) and the debt ratio. The fact that the tax argument does not have a lot of support among small businesses is consistent, for instance, with Kashefi-Pour et al. (2010). 
Table 4. Debt and tax rates.

\begin{tabular}{ccccc}
\hline & & $\begin{array}{c}\text { Total Debt Provided/(Total } \\
\text { Debt + Total Equity) }\end{array}$ & $\begin{array}{c}\text { Average Debt/(Average } \\
\text { Debt + Average Equity) }\end{array}$ & $\begin{array}{c}\text { Small Business } \\
\text { Tax Rate }\end{array}$ \\
\hline \multirow{2}{*}{ All SMEs } & $\begin{array}{c}1 \text { to } 499 \\
\text { employees }\end{array}$ & 0.876402 & 0.370954 & \\
\hline \multirow{5}{*}{ Region } & Atlantic & 0.877895 & 0.281993 & $14.3^{*}$ \\
& $\begin{array}{c}\text { Quebec } \\
\text { Ontario }\end{array}$ & 0.908257 & 0.339092 & 15.49 \\
& $\begin{array}{c}\text { Manitoba } \\
\text { Saskatchewan } \\
\text { Alberta } \\
\text { British Columbia } \\
\text { and Territories }\end{array}$ & 0.884781 & 0.452786 & 15.5 \\
& 0.948693 & 0.468568 & 11 \\
& 0.896066 & 0.386107 & 14 \\
\hline
\end{tabular}

* Average among Nova Scotia, Newfoundland and Labrador and New Brunswick. ${ }^{* *}$ Average among British Columbia and Northwestern Territories.

Table 5. Correlation coefficients $(X-Y)$.

\begin{tabular}{ccc}
\hline $\mathbf{X}$ & \multicolumn{1}{c}{$\mathbf{Y}$} & Corr \\
\hline Small business tax rate & Total debt provided/(total debt + total equity) & -0.0126 \\
Small business tax rate & Average debt/(average debt + average equity) & -0.019 \\
\hline
\end{tabular}

Sources: http://www.taxplanningguide.ca/tables/corporate-taxation-cpp-ei/table-1-business-income-eligible-sbd/. Statistics Canada, Survey on Financing and Growth of Small and Medium Enterprises 2011.

Table 6. International debt and tax rates for SMEs.

\begin{tabular}{|c|c|c|c|c|c|c|c|}
\hline \multirow{3}{*}{$\begin{array}{l}\text { Targeted } \\
\text { Corporate } \\
\text { Income Tax }\end{array}$} & \multirow{2}{*}{\multicolumn{2}{|c|}{$\begin{array}{c}2015 \\
\begin{array}{c}\text { Small Business Corporate } \\
\text { Tax Rates }\end{array}\end{array}$}} & \multicolumn{4}{|c|}{2014} & \\
\hline & & & \multicolumn{3}{|c|}{ SME Financing Sources } & \multirow{2}{*}{$\begin{array}{c}\text { Business } \\
\text { Loans/(Business } \\
\text { Loans + VC) }\end{array}$} & \\
\hline & $\begin{array}{c}\text { Central } \\
\text { Government }\end{array}$ & $\begin{array}{l}\text { All Levels of } \\
\text { Government }\end{array}$ & Unit & $\begin{array}{c}\text { Business } \\
\text { Loans, SME }\end{array}$ & $\begin{array}{c}\mathrm{VC} \\
\text { Investments }\end{array}$ & & \\
\hline \multicolumn{8}{|l|}{ Country } \\
\hline Belgium & 24.25 & 24.98 & EUR mil & 109776 & 0.323408 & 0.99999705 & $\begin{array}{l}\mathrm{VC}+\text { growth } \\
\text { capital }\end{array}$ \\
\hline Canada & 11 & 15.19 & CAD bil & 93.7 & 2.4 & 0.97502601 & $\begin{array}{l}\mathrm{VC}+\text { growth } \\
\text { capital }\end{array}$ \\
\hline France & 15 & 15 & EUR mil & 219647 & 3234 & 0.98549001 & $\mathrm{VC}+$ growth \\
\hline Hungary & 10 & 10 & HUF mil & 4831238 & 18759 & 0.99613216 & \multirow{5}{*}{$\begin{array}{l}\mathrm{VC}+\text { growth } \\
\text { capital }\end{array}$} \\
\hline Japan & 15 & 21.42 & JPY tril & 251.7 & 0.117 & 0.99953538 & \\
\hline Korea & 10 & 12.2 & KRW tril & 522.43 & 1.6393 & 0.99687198 & \\
\hline Netherlands & 20 & 20 & EUR bil & 18 & 0.434 & 0.97645655 & \\
\hline Spain & 25 & 25 & $\begin{array}{c}\text { EUR bil, } \\
2013\end{array}$ & 134 & 0.555 & 0.99587529 & \\
\hline $\begin{array}{l}\text { United } \\
\text { States }\end{array}$ & 15 & 19.92 & USD mil & 589772 & 50297 & 0.92141941 & $\begin{array}{l}\text { Growth } \\
\text { capital }\end{array}$ \\
\hline
\end{tabular}

Sources: http://www.keepeek.com/Digital-Asset-Management/oecd/industry-and-services/financing-smes-andentrepreneurs-2016_fin_sme_ent-2016-en\#page118; http://stats.oecd.org//Index.aspx?QueryId=59543.

Table 7. Correlation coefficients $(X-Y)$.

\begin{tabular}{ccc}
\hline Y & $\mathbf{X}$ & Corr \\
\hline Business Loans/(Business Loans + VC) & Small business corporate tax rates (Central Government) & 0.0006 \\
Business Loans/(Business Loans + VC) & Small business corporate tax rates (All levels of Government) & -0.0002 \\
\hline
\end{tabular}

The life cycle theory of capital structure (Damodaran 2003) argues that mature firms should have higher debt ratios compared to younger firms.

Table 8 shows that young firms have lower debt ratios than older firms (H7), which is consistent with the life cycle theory. 
Table 8. Debt and firm age.

\begin{tabular}{cccc}
\hline & Numbers (Average) & $\begin{array}{c}\text { Total Debt Provided/(Total } \\
\text { Debt + Total Equity) }\end{array}$ & Liabilities/Assets \\
\hline All SMEs & 1 to 499 employees & 0.876402 & 0.493849 \\
\hline \multirow{3}{*}{ Age of Business } & $2009-2011$ (2 years or younger) & 0.442206 & 0.382821 \\
& 2001-2008 (3 to 10 years old) & 0.753462 & 0.493482 \\
& 1991-2000 (11 to 20 years old) & 0.902901 & 0.459491 \\
& Prior to 1991 (more than 20 years old) & 0.930078 & 0.515598 \\
\hline
\end{tabular}

Sources: Statistics Canada, Survey on Financing and Growth of Small and Medium Enterprises 2011.

Crowdfunding. Table 9 presents the statistics of crowdfunding data for Canada by provinces.

The regression results are reported in Table 10. The results show that the number of crowdfunding providers is positively associated with the provincial population, internet access and entrepreneurial support. The relationship with GDP per capita and the market income per capita is insignificant. In general, the regression results are very strong. Ideally, raising funds via the internet should remove geographical barriers for firms (Agrawal et al. 2010). However, the analysis suggests that provincial features are important for crowdfunding data. It may be related to the cost and efficiency arguments. First, consider them on the supply side. From the providers' point of view, the population size provides an indication of potential economies of scale for their business. Note that crowdfunding regulation in Canada is two-fold: there is the federal level and the provincial level as well. As we discussed in the previous section, some provinces are more advanced in terms of regulation on crowdfunding, e.g., Ontario. Hence, providers of crowdfunding services understand that their services depend on the regulations, and, therefore, the provincial population is a strong factor for them. Provinces with a small population do not have a significant number of providers. Secondly, on the demand side, the population can reflect the potential amount of feedback and benefits funders can receive from a platform (Belleflamme et al. 2014): a large platform implies more interactions between funders and, therefore, more benefits for many of them (see, for example, Belleflamme et al. 2015). GDP per capita does not have a significant impact, probably because the difference between provinces is minimal. Perhaps it also reflects the idea that crowdfunding is suitable for different types of investors, including small and large ones. Entrepreneurial reputation has a positive impact on the number of crowdfunding providers. These results also suggest that cost and efficiency are important factors for crowdfunding. This also contributes to recent debates about local bias in crowdfunding (see, e.g., Hornuf et al. 2020). 
Table 9. Crowdfunding statistics for Canada.

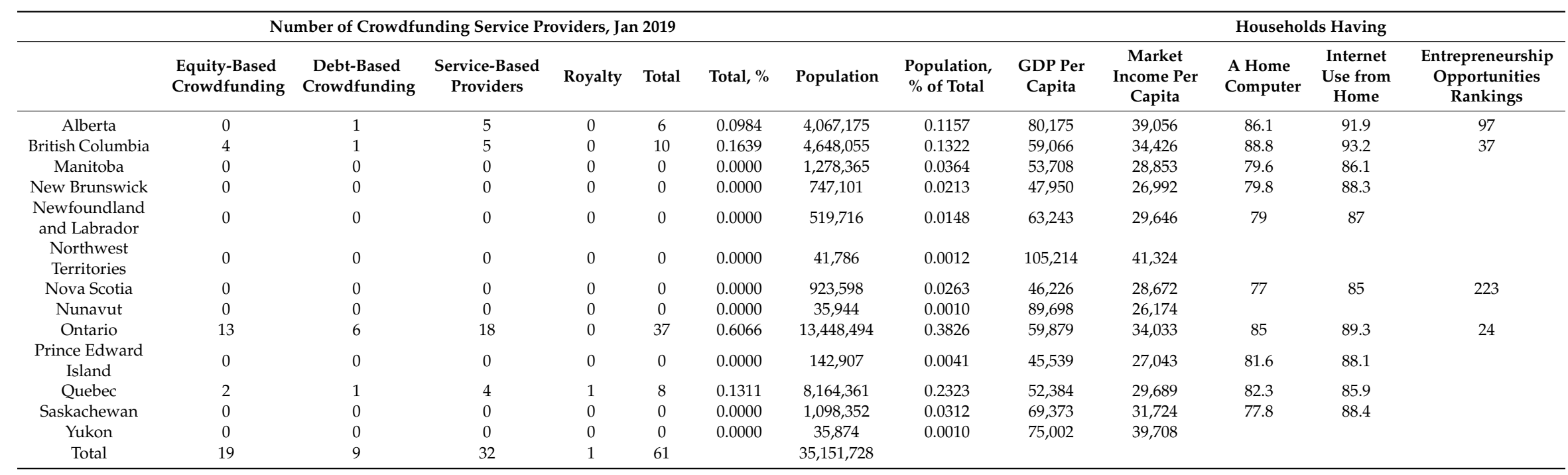

Sources: https://www150.statcan.gc.ca/t1/tbl1/en/tv.action?pid=1110022801\&pickMembers\%5B0\%5D=1.5; https://www.startupblink.com/; https://en.wikipedia.org/wiki/Population_of_
Canada_by_province_and_territory. 
Table 10. Regression results. The dependent variable is the number of crowdfunding providers (2019) ratio.

\begin{tabular}{cccc}
\hline Variables & $\mathbf{( 1 )}$ & $\mathbf{( 2 )}$ & (3) \\
\hline Intercept & $-0.0910(-0.7535)^{*}$ & $-1.4917(-1.2905)^{* * *}$ & $0.5889(0.6729)^{* * *}$ \\
Population & $1.4026(7.7045)^{* * *}$ & $1.7009(5.064)^{* * *}$ & $1.0872(4.2437)^{* * *}$ \\
GDP/capita & $6.4698 \times 10^{-7}(0.4431)$ & $-4.4505 \times 10^{-6}(-0.7015)$ & $9.1594 \times 10^{-6}(1.7314)$ \\
Market income/capita & $5.5746 \times 10^{-7}(0.1105)$ & $5.8075 \times 10^{-6}(0.2473)$ & $-0.0001(-2.2404)$ \\
Households having a home computer & & $-0.0272(-1.3228)$ & $-0.0004(-0.0343)$ \\
Households having Internet use from home & & $0.0421(1.5887)^{*}$ & $0.0017(0.0926)^{* *}$ \\
entrepreneurship opportunities rankings & & & $0.0967(3.3395)^{* *}$ \\
Adj. $R^{2}$ & 0.8459 & 0.8384 & 0.9543 \\
F-value & 22.9649 & 10.3405 & 32.3468 \\
\hline
\end{tabular}

${ }^{* * *}$ indicates significance at a $1 \%$ level, ${ }^{* *}$ indicates significance at a $5 \%$ level, and ${ }^{*}$ indicates significance at a $10 \%$ level.

\section{Limitation Analysis}

The limitations of our analysis are mostly related to data availability. Statistics Canada conducts an entrepreneurs' survey every 3-4 years. If these data were available on an annual basis, this would lead to more precise results. Secondly, much more data is needed to analyze the patterns of crowdfunding. The data are very limited as of now. Much more data are expected in the future, including features of the firms conducting different types of crowdfunding campaigns (including their accounting and financial data), and not only the campaign features themselves. In general, it is known that small business data are more limited compared to large public companies. Nevertheless, recent developments in online accounting and other areas of Fintech will hopefully reduce the cost of collecting information for small firms, which can lead to more data about these firms in the future. Statistics Canada provides an enormously helpful service for researchers by conducting these surveys, but, in the future, it would be good to have more detailed information about the businesses and their operations.

\section{Conclusions}

This article analyzes the patterns of financing for entrepreneurial firms in Canada. We compared the predictions of the major theories of entrepreneurial finance (the flexibility theory of capital structure, the asymmetric information theory, the credit rationing theory, and the life cycle theory) with empirical evidence. We found, for example, that the flexibility theory and the credit rationing theory are consistent with many patterns of financing of SMEs in Canada. On the other hand, the tax theory of capital structure does not seem to play a significant role for SMEs, as opposed to large companies, but it may affect the choice of securities by firms that use venture capital. New forms of financing, such as crowdfunding, are on the rise. Ideally, raising funds via the internet should remove geographical barriers for firms. However, the analysis suggests that provincial features such as population size are important for crowdfunding data. It suggests that cost and efficiency are important factors for crowdfunding, and future research should continue aiming at revealing the most important factors that can help reduce the costs and improve the efficiency of crowdfunding campaigns.

As was mentioned, credit rationing plays a significant role in explaining the patterns of financing for entrepreneurial firms in Canada. Hence, debt financing is strongly affected by such factors as firm age, its size and firm owner's origin. In addition, small business interest rates margins are higher in Canada compared to average numbers from OCDE countries. As an avenue for future research, we think more ideas should be received regarding debt financing developments for entrepreneurial firms. This is consistent with a new wave of interest towards debt financing among theorists and practitioners (see, for example, Robb and Robinson 2012; Miglo 2016, chp. 8; Miglo 2020). Potential developments in this area can be related to improvements in intellectual property rights and patents and the usage of patents as collateral for loans, which is consistent with observed patterns in other countries (Gallini and Hollis 2019; Mann 2018; Bellucci et al. 2014). With regard to Canada, note that some researchers have pointed out that the Canadian ratio of patents to GDP is relatively low compared 
to other developed countries (Gallini and Hollis 2019) and that Canadian researchers often participate in joint research with researchers from other countries (mostly US) but do not own the intellectual property rights of much of the research. Gallini and Hollis (2019) have suggested several directions for potential improvements in this area of intellectual property regulation. Given our previous point that intellectual property and patents are directly related to debt financing (including SMEs that are responsible for a large part of innovative activities), this can be the next step in improving debt financing for SMEs in Canada.

As was previously mentioned, although crowdfunding is a new and potentially more efficient way of financing for entrepreneurial firms as compared to traditional financing, the analysis shows that cost and efficiency are important factors for crowdfunding and research should continue aiming at revealing the most important factors that can help to reduce the costs and improve the efficiency of crowdfunding campaigns. Perhaps, in the future, the focus of research should be on factors such as asymmetric information (Miglo and Miglo 2019), moral hazards (Strausz 2017; Chemla and Tinn 2019; Schwienbacher 2018), and behavioural finance elements (Fairchild et al. 2017) ${ }^{14}$, discovered in the literature on crowdfunding. With the accumulation of more data, more research is expected in these areas.

Finally, note that a high-quality education system is an essential part of the successful development of entrepreneurial finance in Canada. It is hard to overstate the importance of education since the area is very complicated and requires a superior knowledge of econometrics, microeconomics, accounting, mathematics, game theory, contracts and law. Part of the research done for this article was collecting information about existing finance programs in Canada ${ }^{15}$. Finance programs exist in most universities. Most of them are not specifically focused on small- or medium-sized companies. Some universities, however, are working on creating such a program. For example, Nipissing University is implementing a finance program that offers a certificate in entrepreneurial finance, and many universities, including the University of British Columbia, McGill, and Western University, offer entrepreneurial finance and/or small business finance lectures/courses.

Funding: This research received no external funding.

Acknowledgments: I thank two anonymous referees, Jin Chen, Victor Miglo, Camilo Jimenez, Jason Pavunkovic, Bilal Maycid, Jonathon Dean, Zara Raza, Isabelle Mineault, Greg Charbonneau, Markus Hawco, Melissa Toner, Jacob Conrad and seminar participants of SME workshop at BCU at 2017 for their comments and for helping with research on some topics. Also many thanks to assistant editors Grace Yue and Ramona Goga for their help and encouragement.

Conflicts of Interest: The author declares no conflict of interest.

\section{Appendix A}

\section{Appendix A.1. Sources of Financing for Entrepreneurial Firms in Canada}

\section{Appendix A.1.1. Debt Financing}

In 2011, 36 percent of SMEs requested some type of external financing, with 26 percent requesting debt, 7 percent requesting leasing, 8 percent requesting trade credit, 4 percent requesting government financing and 2 percent requesting equity financing ${ }^{16}$. In 2014, the fraction of SMEs requesting external financing and debt rose to 51.3 percent and 28.1 percent, respectively.

Table A1 shows the major suppliers of small business debt financing in Canada and the percentage of firms indicating their source financing. Chartered banks were the main suppliers of financing to SMEs in 2011 and 2014, followed by credit unions and caisses populaires. Microloans and community investment funds are two other loan sources. Examples include Alterna Savings, which is Ontario's

14 See also Belitski et al. (2019).

15 We mostly use publicly available information from university and college websites.

16 Some firms requested more than one type of external financing. 
second-largest credit union. Community investment funds are nonprofit organizations dedicated to helping people in Canada who cannot get the loans they need from traditional lending institutions. Depending on the particular loan fund, an individual may be able to get a small business loan from CAD2000 up to CAD150,000. In general, the Canadian banking system looks pretty balanced with regard to serving small businesses (Klyuev 2008). Large banks have good international reputations, although some surveys show that entrepreneurs often feel that large Canadian banks are pretty distant from small firms ${ }^{17}$. Hence, other credit institutions serve as a good complement to large banks.

A part of debt financing is the growing area of online lending, which is a part of crowdfunding, and it is considered in Appendix A.1.4. Government lending to SMEs is considered in Appendix A.1.2.

Commercial lines of credit, used by $13.8 \%$ of SMEs in 2014, are the most used type of external funding, followed by commercial credit cards (11.2\%) and commercial loans (6.9\%).

Table A1. Major sources of debt financing in Canada (by the percentage of firms among firms requesting external financing).

\begin{tabular}{ccc}
\hline \multirow{2}{*}{ Source } & \multicolumn{2}{c}{ Percentage } \\
\cline { 2 - 3 } & $\mathbf{2 0 1 1}$ & $\mathbf{2 0 1 4}$ \\
\hline Chartered banks & $55.3 \%$ & $71.6 \%$ \\
Credit Unions and Caisses Populaires & $16.3 \%$ & $24.7 \%$ \\
\hline Source: Statistics Canada, Survey of Suppliers of Business Financing 2011, 2014.
\end{tabular}

The data on SME loans in OCDE countries demonstrate different patterns of growth for different countries. The outstanding stock of SME loans in 2013 was still below the prerecession levels of 2007 in 7 out of the 18 countries for which comparable data was available (Estonia, Hungary, Ireland, Japan, Portugal, the United Kingdom and the United States). Although economic growth in OECD countries recovered in 2010, increasing annually on average by $6.5 \%$, SME lending in most countries did not follow and, in some countries, declined even further in the following years. Canada is in the middle of the range among OCDE countries in terms of the growth rate of SME loans. The total value of SME loans increased from CAD86,428 million in 2009 to CAD90,172 million in $2013^{18}$.

The 2013 Credit Conditions Survey results showed that credit conditions remained stable after having recovered from the 2009 recession. The average interest rate charged to small businesses has increased by 0.3 percentage points since 2011 , reaching $5.6 \%$. The average business prime rate (the rate charged to the most creditworthy borrowers) stayed flat at $3 \%$. The business risk premium (measured as the difference between the average small business interest rate and the business prime rate) increased from $2.3 \%$ in 2011 to $2.6 \%$ in 2013. This reflects stable access for debt financing for small businesses in Canada.

In 2007-2010, in most countries, SMEs faced more severe credit conditions than large enterprises in the form of higher interest rates, shortened maturities and increased requests for collateral (OECD 2012). Between 2007 and 2013, the interest rate spread between large firms and SMEs widened considerably for most Scoreboard countries for which data is available, with the exception of Belgium, Canada, Colombia, Korea, Serbia, Sweden and the United States.

In 2013, the collateral requirements decreased in seven out of ten countries. This marked a deviation from the trend in previous years. Canada, Finland and the United Kingdom witnessed an increase in the proportion of loans that were rejected in 2013. Overall, it seems like there were a few factors according to which the credit conditions loosened in most countries between 2011-2014, like softer collateral requirements. For example, in Canada, the percentage of small businesses asked to pledge collateral to secure their loans returned to 2009 levels (56\%).

17 See, for example, Kazarian and McFarland (2016); Kelly (2013); Saltzman (2015).

18 OCDE SME Financing 2015. 
It is well known that the Canadian economy is closely related to the US economy. In contrast to Canada, however, in the USA, the total value of SME loans decreased from USD695,228 million in 2009 to USD585,347 million in 2013. Hence, an interesting question is whether the difference between Canada and the USA can be explained by the difference in credit conditions and whether or not the credit conditions are softening in Canada. On the one hand, we can see, for example, that interest rates for SMEs in Canada increased in 2013, unlike any other country. Additionally, the total volume of loans in Canada increased even more than loans to SMEs. Finally, Canada witnessed an increase in the proportion of loans that were rejected in 2013. On the other hand, the percentage of small businesses asked to pledge collateral to secure their loans decreased in 2014 and returned to 2009 levels.

Appendix A.1.2. Government Funding and International Foundations

Government grants and loans are used by $20.9 \%$ of Canadian SMEs. Additionally, as was mentioned above, government institutions serve $7 \%$ of all financing requests. Table A2 shows the major government programs.

Table A2. Major government programs.

\begin{tabular}{|c|c|}
\hline Program & Main Features \\
\hline $\begin{array}{l}\text { Canada Small } \\
\text { Business Financing } \\
\text { (CSBF) Program }\end{array}$ & $\begin{array}{l}\text { Term loans of up to CAD } 500,000 \text { for acquiring real property and equipment and making } \\
\text { leasehold improvements. The government is liable to pay } 85 \% \text { of eligible losses on defaulted } \\
\text { loans registered under the program, which allows private-sector lenders to comfortably } \\
\text { increase the amount of financing extended to small businesses. The program is supported by } \\
\text { charging } 3 \% \text { above prime and a } 2 \% \text { registration fee paid by the borrowers. The repayment of } \\
\text { the loan can be amortized over a period longer than } 10 \text { or } 15 \text { years. }\end{array}$ \\
\hline $\begin{array}{l}\text { Business Development } \\
\text { Bank of Canada (BDC) }\end{array}$ & $\begin{array}{l}\text { Loans up to CAD100,000. The business should be Canadian-based. For the duration of the } \\
\text { COVID- } 19 \text { crisis, the small business loan is offered at a } 2.80 \% \text { interest rate, which is BDC's } \\
\text { floating base rate of } 4.55 \% \text { (effective } 31 \text { March } 2020 \text { ) minus } 1.75 \% \text {. The interest rate is subject to } \\
\text { change without notice. The loans are repaid over } 60 \text { months. A capital postponement is } \\
\text { offered for the first } 6 \text { months, and the initial six payments are interest only. Commencing on } \\
\text { the 7th month, the loan is repaid in } 60 \text { monthly payments, and all payments are due on the } \\
\text { 10th day of the month. }\end{array}$ \\
\hline CanExport & $\begin{array}{l}\text { Funding is provided on a cost-sharing basis between the recipient and CanExport SMEs. } \\
\text { The program reimburses up to } 75 \text { percent of eligible expenses; the applicant is responsible for } \\
\text { the remaining } 25 \% \text { (in-kind contributions do not count toward the } 25 \% \text { ) }\end{array}$ \\
\hline $\begin{array}{l}\text { Futurpreneur Canada } \\
\text { (former Canada Youth } \\
\text { Business Foundation) }\end{array}$ & $\begin{array}{l}\text { Several different financing programs to support entrepreneurs aged } 18 \text { to } 34 \text {, including one } \\
\text { that provides start-up small business loans of up to CAD } 20,000 \text { with a term over five years. } \\
\text { Interest is charged at CIBC's prime rate }+3.75 \% \text {. Interest-only payments for the first year. } \\
\text { Principal repayments are made in equal monthly instalments together with interest, over the } \\
\text { remaining four years. } \\
\text { No penalty for early repayment. }\end{array}$ \\
\hline $\begin{array}{l}\text { Aboriginal Business } \\
\text { Canada }\end{array}$ & Grants of up to CAD99,999 for eligible individual Aboriginal entrepreneurs \\
\hline $\begin{array}{l}\text { Western Economic } \\
\text { Diversification } \\
\text { Canada (WD) }\end{array}$ & $\begin{array}{l}\text { Several programs (e.g., Western Innovation Initiative, Community } \\
\text { Futures Loan Program) to strengthen western innovation, } \\
\text { business development and community economic development. }\end{array}$ \\
\hline $\begin{array}{l}\text { Alberta Micro } \\
\text { Voucher Program }\end{array}$ & $\begin{array}{l}\text { Eligible applicants can apply for up to CAD10,000, paid directly to the service provider, } \\
\text { to cover eligible expenses charged by the service provider for the purpose of one or more of } \\
\text { the following activities: } \\
\text { New product research and development; design, engineering and prototype development; } \\
\text { product testing and refinement; patent development (excluding patent maintenance fees); } \\
\text { advanced market assessment or segmentation analysis; advanced business and/or marketing } \\
\text { strategies; other technology development activities that will be considered on a case-by-case } \\
\text { basis. The applicant pays a minimum } 25 \% \text { cash contribution of the total eligible project costs. }\end{array}$ \\
\hline
\end{tabular}

Sources: https://www.ic.gc.ca/eic/site/csbfp-pfpec.nsf/eng/la03089.html; https://www.bdc.ca/en/financing/businessloans/pages/small-business-loan-up-50k.aspx?gclid=CLqHjpuqjs0CFQyEaQodltAI7g; http://www.international. gc.ca/canexport/applicant-guide-requerant.aspx?lang=eng; http://www.futurpreneur.ca/en/get-started/financingand-mentoring/spin-master-innovation-fund/?gclid=COjtvOKqjs0CFQsPaQodJKMGJw; https://www.aadnc-aandc. gc.ca/eng/1375201178602/1375202816581; http://www.wd.gc.ca/eng/259.asp; https://albertainnovates.ca/programs/ micro-voucher/. 
The CSBF Program aims to increase the availability of financing for the establishment, expansion, modernization and improvement of small businesses. It insures a portion of loans made to qualifying small businesses by the private sector. It supports some 10,000 financings valued at around CAD1 billion each year. Under the CSBF Program, Industry Canada and commercial lenders share the risk of providing small businesses with term loans of up to CAD500,000 for acquiring real property and equipment and making leasehold improvements. The government is liable to pay $85 \%$ of eligible losses on defaulted loans registered under the program, which allows private-sector lenders to comfortably increase the amount of financing extended to small businesses. The program is supported by charging $3 \%$ above prime and a $2 \%$ registration fee paid by the borrowers. A lot of research has been done to evaluate the efficiency of different programs, including CSBF. Much of it shows the significant economic impact of these programs. ${ }^{19}$

The Business Development Bank of Canada (BDC) has a mandate to "create and develop Canadian businesses through financing, venture capital and consulting services" ${ }^{20}$. The bank supports more than 29,000 Canadian small and medium enterprises (SMEs) with financing and other commitments valued at some CAD17.7 billion.

On 5 January 2016, the Minister of International Trade launched CanExport, a new program that will provide $\$ 50$ million over five years to help increase the competitiveness of export-ready small- and medium-sized enterprises (SMEs) that target new export opportunities. It is open, with few exceptions, to all industry sectors and to companies looking at export markets worldwide. To be considered for possible funding, a firm must meet the following basic criteria: be a for-profit company, be an incorporated legal entity or a limited liability partnership (LLP), have a Canada Revenue Agency (CRA) business identifier number, have a minimum of one full-time equivalent (FTE) employee and a maximum of 250 FTE employees, and have no less than CAD200,000 and no more than CAD50 million in annual revenue declared in Canada.

Other notable programs include the Futurpreneur Canada (former Canada Youth Business Foundation-a charitable organization heavily supported by the government), Export Development Corporation (EDC), Aboriginal Business Canada and Indian and Northern Affairs Canada. Futurpreneur Canada helps young entrepreneurs by providing mentorship, learning resources and start-up financing when commercial lending is unavailable. It offers several different financing programs to support entrepreneurs aged 18 to 34, including one that provides start-up small business loans of up to CAD15,000. Founded in 1996, this program has invested in more than 3300 young people, whose businesses have generated more than 16,600 new Canadian jobs, CAD93 million in tax revenue and hundreds of millions of dollars in sales and export revenue. Export Development Corporation (EDC) supports large and small businesses with critical export financing; of its 8300 clients, about $80 \%$ are SMEs. Although EDC does not offer any grants, they do offer loan guarantees for companies exporting their products. If a company expects to export products and wants to minimize its risk, EDC is a great resource. Aboriginal Business Canada offers grants of up to CAD99,999 for eligible individual Aboriginal entrepreneurs. Indian and Northern Affairs Canada has made progress in increasing the participation of Aboriginal entrepreneurs in the Canadian economy through the Aboriginal Business Development Fund ${ }^{21}$.

19 For references regarding research on economic efficiency of different government programs, including CSBF, see, for example, https://www.ic.gc.ca/eic/site/ae-ve.nsf/eng/03111.html.

20 BDC is a Crown corporation. Canadian Crown corporations are enterprises owned by the Crown or Queen in right of Canada. They report to the government via a minister of the Crown in the relevant cabinet, though they are "shielded from constant government intervention and legislative oversight" and thus "generally enjoy greater freedom from direct political control than government departments". For more information, see, for example, Iacobucci and Trebilcock (2012).

21 Other programs include the Business Credit Availability Program (BCAP), the Hiring Credit for Small Business, and Canada Job Fund Agreements, which include the introduction of the Canada Job Grant (CJG), programs offered by the Federal Economic Development Agency for Southern Ontario (FedDev Ontario), Advanced Manufacturing Fund (AMF), Export Development Canada (EDC), the Business Innovation Access Programme, to be delivered through the National Research Council's Industrial Research Assistance Programme (NRC-IRAP), programs offered by Sustainable Development Technology Canada, the Canada Accelerator and Incubator Programme (CAIP) and the Women Entrepreneurs of Canada (WEC). 
Microloans and community investment funds are two other loan sources. In Canada, microloans of up to CAD15,000 are available through some organizations for people who would have difficulty getting a traditional business loan. Examples include Western Economic Diversification Canada, a government entity in western Canada that works to strengthen western innovation, business development and community economic development.

Many governments, including the Canadian government, offer entrepreneurs opportunities to access alternative financing options that are often nonequity and nondebt based ${ }^{22}$. The types of financing that offer these opportunities can be found through the Government of Canada, both provincially and federally, as well as through entrepreneurship competitions and international organizations. Grants and dual contribution grants offered by the Canadian Government can take a number of forms. First, there are full, nonrepayable grants. The majority of them are aimed at research and development (R\&D) projects. In order to gain access to these R\&D grants, a business typically, but not always, needs to be performing $R \& D$ in partnership with a researcher, usually affiliated with a university. Since there are a lot of risks and uncertainties surrounding $R \& D$ in general and in decision-making regarding grants allocation, it is always good from the government's point of view to see that companies are making an effort to gain financial support from other sources as well. To some extent, it reduces the government's responsibility and risk as the main funder, but most importantly, it also increases business credibility ${ }^{23}$. Thus, the second type of grant available is a dual contribution grant. These are more often the type of grant available to businesses and are often nonrepayable. They do, however, require the business to contribute in some way to the project being funded. Some programs require the company to match the government's financial contribution. This matching could be done using the companies' own funds or funds from another source, such as bootstrapping, angel investors or venture capital. The reason for this is that it allows the government to gauge how the market views the opportunity (Lerner 2009). Matching requirements differ between programs. There could be a one-for-one matching requirement, where the company's contribution needs to be monetarily equivalent to the government's; other funds may have a different matching ratio requirement. The matching requirement could only require a partial monetary contribution along with "in-kind" contributions. For example, if a government grant is being used to fund the hiring of staff, an in-kind contribution could take the form of mentorship for the new staff members or supporting their professional development.

Vouchers are a relatively new funding tool. In some cases, it helps entrepreneurs to access business services via prepaid funds. Vouchers can be administered by the government, universities and business plan competitions. Services usually include business planning, market research, intellectual property strategy, grant writing, and access to discounted rates ${ }^{24}$. The Microvoucher, Voucher and Product Demonstration Program of the government of Alberta could help your Alberta-based business to commercialize its innovative products and services. It includes, among others, the microvoucher that provides up to CAD10,000 to assist with early start-up development. ${ }^{25}$

The EY G20 Entrepreneurship Barometer 2013 introduces a model for scoring G20 countries across the five pillars of entrepreneurship ${ }^{26}$. Canada has scored pretty well in terms of overall funding opportunities for entrepreneurs. However, Canada scores poorly on several dimensions regarding government support, including mentorship, the provision of incubators by businesses and universities, and the availability of networks such as entrepreneur clubs and associations. This explains why Canada's entrepreneurs are calling for more government start-up programs and better access to

\footnotetext{
22 See also Cumming and Hellmann (2013) and Taylor (2012).

23 More discussion regarding this point will be provided in the next section.

24 See Cumming and Hellmann (2013); Funding Portal (2013).

25 http://www.entreprisescanada.ca/eng/program/2415/, https://albertainnovates.ca/programs/micro-voucher/.

26 http://www.ey.com/CA/en/Services/Strategic-Growth-Markets/G20-Entrepreneurship-Barometer-2013-Overview.
} 
business incubators and mentoring programs. This is also consistent with previous years' results of some surveys, when many entrepreneurs felt that that government programs need improvement ${ }^{27}$.

Compared to other OCDE countries, the amount of government loan guarantees in 2013 was below the 2007 and 2009 levels (2007 was the precrisis level, and 2009 was the year of large government capital injections to support small businesses after the crisis). In most countries, the volume of government guaranties in 2013 was higher than in 2007 (the exceptions are Austria, Finland, Greece, United Kingdom). Direct government loans were below their level of 2009, although slightly higher than that of 2007.

There are a large number of prizes offered by international foundations and organizations; some governments may even have programs for international development (e.g., the USAID Development Innovation Venture). The prizes offered by international foundations and organizations can take the form of international recognition and/or monetary rewards. Some are focused on start-up companies; others consider companies or individuals that have already made a significant contribution to their field. Typically, there are well-defined criteria for each prize, including commitments required by winners of these awards, as they are often expected to be involved in the promotion of their results. Additionally, there are a number of business plan competitions that take place every year ${ }^{28}$. These events offer start-ups a significant amount of publicity to the entrepreneurial community, as well as the potential to receive funding through prizes or investments. The top applicants are usually asked to present their business plan to a panel of judges. Some competitions require initial business plan submissions, after which the top applicants are taken through a mentoring program to improve their initial business plans, after which the improved business plans are presented to a panel of judges. The competition judging panels typically consist of a combination of entrepreneurs, industry experts, "angel" investors and venture capitalists. The panel chooses the best business plan(s) based on the presentation.

Among the most recent government programs of support for SME loans is, notably, CEBA, an emergency program of support during the 2020 COVD-19 crisis. Scotiabank, together with other leaders in the banking community, has been consulting with the government on these measures, designing them specifically to help small business owners with their most pressing needs in order to position the economy to recover. The CEBA program provides access to a CAD40,000 loan with the following features: 0\% interest until 31 December 2022; no principal payments until 31 December 2022; principal repayments can be voluntarily made at any time without fees or penalties ${ }^{29}$.

\section{Appendix A.1.3. Equity Financing}

SMEs receive equity financing in the form of the entrepreneurs' own funds, "sweet" equity from family and friends, angel financing, venture capital and equity-based crowdfunding. As was mentioned previously, most start-up firms use their own funds and funds from friends and relatives since profits are limited or inexistent and external funds are hard to obtain. The percentage of SMEs that use venture capital to start-up business is not large (see Table A3). Entrepreneurial firms begin to look for venture capital at later stages.

Venture capitalists provide support to entrepreneurs in the form of equity or equity-linked investments, as opposed to "pure" debt. Hence, they usually play an active role in the company. Cumming (2006) argues that Canadian venture capital-backed firms receive financing via issuing common equity, preferred equity, warrants, convertible debt and convertible preferred equity.

27 The CGA Entrepreneurship Survey found that $52 \%$ of members viewed government support for entrepreneurship as only being fair, with $26 \%$ of members viewing it to be poor.

28 For example, the Startup Canada Awards (http://startupaward.ca/2016-awards/) or Queen's Entrepreneurs' Competition (http://theqec.com/).

29 https://www.scotiabank.com/ca/en/personal/scotia-support/business-banking/small-business/canada-emergencybusiness-account.html. 
Cumming (2006) also argues that unlike US venture capital firms, convertible preferred equity is not the most dominant type of security due to regulation differences between the US and Canada.

Table A3. Percentage of start-up firms that used different types of equity financing in Canada.

\begin{tabular}{ccc}
\hline \multirow{2}{*}{ Source } & \multicolumn{2}{c}{ Percentage } \\
\cline { 2 - 3 } & $\mathbf{2 0 1 1}$ & $\mathbf{2 0 1 4}$ \\
\hline Personal financing & $79.5 \%$ & $84.3 \%$ \\
Retained earnings (from previous or other business) & $13.0 \%$ & $13.3 \%$ \\
Financing from angel investors and venture capital providers & $0.6 \%$ * & $1.8 \%$ \\
\hline
\end{tabular}

Industry Canada (2014) shows that venture capital-backed companies grow significantly stronger (in terms of assets, sales, wages and R\&D) than nonbacked companies. At the same time, any significant difference in profitability was not found.

Historically, venture capital financing reached its peak in 2000, and, afterwards, the volumes were not very impressive. In 2009, for example, the total volume of venture capital investments was about 3 times lower than in 2000. Some factors behind this pattern included the tech bubble of 1999/2000 and the great recession of 2008/2009. In addition, in Canada, the venture capital industry had some specific features which lessened its competitiveness compared to, for example, the US. Among these features, note the relatively low listing requirements of Canadian exchanges. As was mentioned previously, this reduces the incentive for SMEs to partner with venture capital firms on the one hand, and on the other hand, it creates a lot of asymmetric information about SMEs (Carpentier and Suret 2010) and difficulties in raising public funds and, respectively, a reduced interest from venture capital firms. Another interesting aspect of the venture capital industry in Canada is the large presence of labour-sponsored venture capital funds (LSVCF) ${ }^{30}$. Historically, they played an important role in the creation of the venture capital industry, especially in Quebec. However, it seems like their institutional structure needs some major revisions in order to move the venture capital industry forward (Cumming and MacIntosh 2006; Cumming et al. 2007; Lerner 2009; MacIntosh 2012; Suret 2008). In 2007-2013, the Canadian venture capital industry was experiencing a very difficult transition. As is the case for many other venture capital industries around the world, the industry was not able to deliver strong enough returns to consistently attract Canadian and foreign institutional investors. As a result, Canada's venture capital investments, as a percentage of GDP, only rank 16th in the world. Financing in the form of venture capital increased by $26.5 \%$ in 2013 to reach CAD1.9 billion but remained below the levels in 2007. Venture capital funds are used by only $12.4 \%$ of SMEs. Interestingly, the volume of venture capital investments at all stages of entrepreneurial firms was lower in 2013 than in 2007, except at later stages (Table A4).

Table A4. Venture and growth capital in Canada, 2007-2013.

\begin{tabular}{ccc}
\hline \multirow{2}{*}{ Source } & \multicolumn{2}{c}{ CAD Million } \\
\cline { 2 - 3 } & $\mathbf{2 0 0 7}$ & $\mathbf{2 0 1 3}$ \\
\hline Seed & 98.2 & 43.3 \\
Early stages & 491 & 332.5 \\
Expansion & 795.5 & 516.5 \\
Later and other stages & 966.5 & 1037.3 \\
\hline
\end{tabular}

Source: OCDE SME Financing 2015.

30 LSVCFs are generally sponsored by labor unions and offer tax breaks from government to encourage retail investors to purchase the funds. Generally, these retail venture capital funds only invest in companies where the majority of employees are in Canada. See Sandler (2004) for a review. 
The situation has been changing since 2013/2014. The government-implemented venture capital support program (The Venture Capital Action Plan) of January 2013 represents a strategy that had several objectives, including deploying CAD400 million in new capital over the next 7 to 10 years and demonstrating that Canada's innovative firms represent superior return opportunities. More specifically, the plan made available CAD350 million to establish up to four "funds of funds" (a "funds of funds" portfolio consists of investments in several venture capital funds) and an aggregate investment of CAD50 million in a few high-performing venture capital funds in Canada. Following a rigorous selection process, the government announced, in fall 2013, the selection of high-performing venture capital funds in Canada to receive an aggregate investment of CAD50 million from the government. New "funds of funds" are expected to attract close to CAD1 billion in private sector investments. On 21 January 2014, the Government announced the first closing of the Northleaf Venture Catalyst Fund, with CAD217 million in commitments. Two other funds, Teralys Capital and Kensington Capital Partners, were announced in 2014.

A Canadian Venture Capital Association (CVCA) report revealed a furious level of venture capital activity at lower-dollar funding levels in 2014: Ontario led the way in dollars invested, while Quebec took the lead in terms of the number of deals (Dingman 2015). Several private or independent companies stood out for their pace of investment, among them Real Ventures (42 deals). BDC Capital Inc., the government agency committed to early-stage startup financing, had 102 deals. There are prominent Series A round funding companies such as Rho Ventures, Relay Ventures and iNovia Capital (14 deals in 2014) ${ }^{31}$. For companies looking to raise an A-round, there are a number of top-tier \$50-million funds. There are two Canadian companies that will open their wallets and spend CAD10 or CAD20 million on a single deal: Toronto-based Georgian Partners Inc. (seven deals in 2014) and OMERS Ventures (nine deals). Some of the biggest funding deals of 2014 were led by US money (the low Canadian dollar makes Canadian investments cheaper for Americans), including Silicon Valley investors such as Accel Partners, Sequoia Capital, and Bessemer Venture Partners, companies with billions of dollars under management. These companies come with advantages in terms of advice from major industry players and introductions to key international markets.

Equity markets around the globe, including public and private markets, were severely impacted by the financial crisis. Most countries in OCDE's report experienced a sharp decline in venture capital and growth capital investments between 2008 and 2010. This decline was uniform over venture capital for seed and early growth investments, later-stage venture capital investments and growth capital investments. In Canada, the total volume of venture capital investments in all stages of entrepreneurial firm development in 2013 was down by 14\%, compared to the level of 2008. Interestingly, expansion capital and later and other stages venture capital increased by $215 \%$ for the same period. This is the highest percentage among all the countries. In fact, the only other countries that saw an increase in later-stage investments are Austria, Finland and Ireland.

It is interesting to compare the situation in the venture capital industry of two close neighbours: Canada and the USA. The venture capital industry is dominated by private firms in the US (more than $80 \%$ ). In Canada, LSVCFs cover almost $40 \%$ of all venture capital investments, and institutional funds have about 15\% (Sandler 2004). Until recently, venture capital investments in Canada were not syndicated, and the venture capital industry was not very well developed in most of Canada, including Ontario and Atlantic provinces (see, for example, Amit et al. 1997). As was mentioned previously, a significant part of this industry in Canada represents LSVCFs. Some research has shown that these funds' profitability is very low (Cumming 2005; Nicholson 2009). The Ontario government cancelled tax reliefs for investors in these funds in 2005. It led to shifts in investment policies for these funds, including a reduction in investments in entrepreneurial companies. Additionally, note that Canadian

31 Types of funding and support available to Canadian companies include accelerators and incubators (no money), angels (under CAD1 million), seed funding (CAD500,000 to CAD2 million), Series A (CAD2 million to CAD5 million) and Series B (CAD5 million or more). 
venture capital companies invest in more companies (proportionally), but the average investment in a company is significantly larger in the US than in Canada, which can explain why the number of high-quality "winners" is larger in the USA. Finally, note that unlike the USA, where the dominant form of contract between entrepreneurs and venture capitalists are convertible preferred shares (i.e., Kaplan and Strömberg 2003), in Canada, venture firms use a variety of securities, including straight common equity, preferred equity and convertible preferred equity (Cumming 2005; Cumming and Johan 2008). Gilson and Schizer (2003) argued that this is because the taxes in the US favour convertible preferred shares.

The wave of success in 2014/2015 might also be explained by factors such as the low Canadian dollar, which makes investments cheaper for foreign investors, primarily US investors, and the fact that Canadian technology companies have attracted interest from the global venture capital community partially as a result of a generous tax incentive through the Scientific Research and Experimental Development (SR\&ED) investment tax credit program. The basic incentive available to any Canadian corporation performing $R \& D$ is a refundable tax credit that is equal to $20 \%$ of "qualifying" $R \& D$ expenditures (labour, material, R\&D contracts, and R\&D equipment). An enhanced 35\% refundable tax credit is available to certain (i.e., small) Canadian-controlled private corporations (CCPCs). As the CCPC rules require a minimum of $50 \%$ Canadian ownership in the company performing R\&D, foreign investors who would like to benefit from the larger 35\% tax credit must accept a minority position in the company, which might not be desirable. The SR\&ED program does not restrict the export of any technology or intellectual property that may have been developed with the benefit of SR\&ED tax incentives. Additionally, we note that Canada has a unique venture exchange in Alberta that has no direct analogue in the world ${ }^{32}$.

Angel investors are investors of high net worth who are willing to provide seed money to businesses, often in exchange for returns of $20 \%$ to $30 \%$ through equity ownership. In Canada, angel investors are currently investing over CAD3 billion in Canadian businesses each year. Industry Canada created a longitudinal dataset of 110 angel-backed firms by linking data from NACO's Canadian Angel Group Surveys of 2010, 2011 and 2012 to Statistics Canada administrative databases. The Angel Group data set provides a reliable picture of the characteristics and activity of the visible angel capital market in Canada. The 2014 Angel Group Survey was completed by 30 angel investment groups. These 30 angel investment groups reported 237 investments and 217 deals in 181 companies in 2014, for a total amount of CAD90.5 million. A higher share of investment went to new companies in 2014, as opposed to existing portfolio companies, which represents a reversal of the trend observed in 2013. Angel group investment activity remains concentrated in Central Canada. Of the CAD90.5 million reported angel investments, 89\% were made in Central Canada, 10\% in Western Canada, and 1\% in Eastern Canada.

\section{Appendix A.1.4. Crowdfunding}

Crowdfunding is the practice of funding a start-up company or a project by raising funds from a large number of people ("crowd"). It is usually performed via the internet ${ }^{33}$. The concept can also be executed through mail-order subscriptions, benefit events, and other methods. Moritz and Block (2014), Cumming and Hornuf (2018), Estrin et al. (2018), and Mochkabadi and Volkmann (2020) provide good reviews of the literature in this field. A small TV show called "Blue Mountain State" had been cancelled by Spike TV in 2010, but in 2014, they decided to make a movie. Spike would not fund them, so they decided to crowdfund through a "Kickstarter" campaign ${ }^{34}$. The BMS movie reached its goal of USD1.5 million in less than a month. This is just one example of how crowdfunding is an important tool for entrepreneurial firms and small business ideas.

32 For more discussion, see Carpentier and Suret (2010).

33 See, for example, Schwienbacher and Larralde (2012).

34 https://dorkofalltrades.net/2015/08/03/go-kickstart-blue-mountain-state-sloots/. 
There are four different types of crowdfunding: equity-based, where investors will receive shares of the company; reward-based, where investors are counting on some extra benefits from the company, like future product discounts, among other things; donation crowdfunding, where donations take place, which is good for nonprofits and causes; debt-based crowdfunding, where the money comes in the form of loans.

Reward-based crowdfunding often includes significant interactions between firms and funders/customers in the form of product feedback. Backers are able to pay different levels of money to receive items such as a Jet Black Pebble Watch with a CAD99 pledge ${ }^{35}$. The highest level, in that case, was a CAD10,000 pledge to receive 100 Pebble watches. Thirty-one people made that pledge. Pebble crowdfunding was a great success and a blueprint for entrepreneurial firms.

Canada is one of the leading countries in the world when it comes to setting up crowdfunding campaigns. Canada ranked 10th in the world for crowdfunding in 2018 by the total amount of funds raised with crowdfunding. Table A5 presents an overview of the main statistics concerning this type of funding in 2014, 2015, 2019 and 2020.

Table A5. Crowdfunding in Canada.

\begin{tabular}{ccccc}
\hline & $\mathbf{2 0 1 4}$ & $\mathbf{2 0 1 5}$ & $\mathbf{2 0 1 9}$ & $\mathbf{2 0 2 0}$ \\
\hline Projects & 9400 & 8677 & 3910 & 4300 \\
Success rate & $21 \%$ & $20 \%$ & $42 \%$ & N/A \\
Average amount per project & CAD14,700 & CAD20,140 & CAD29,517 & CAD4813 \\
\hline
\end{tabular}

Sources: https://www.statiAsta.com/outlook/335/108/crowdfunding/canada, https://p2pmarketdata.com/ crowdfunding-statistics-worldwide/, Canada 2016: The State of Crowdfunding Nation, The Crowdfunding Center. https://www.thecrowdfundingcenter.com/data/places?location=CA.

According to CMF (the Canadian Media Fund), there are many different platforms that vary widely in the way that they are structured. Most crowdfunding platforms solely focus on one model, such as the donation model, but there are some that offer a choice of different models or offer a "hybrid" model that combines elements from one or more of the three key models out there. The three main crowdfunding platforms are

- Specialized platforms that cater to specific industries such as television, music recording and video games.

- General-purpose platforms that do not really have any restrictions as to what they can feature. This platform is the most popular and most recognized as it has spread through social media for funding things like medical procedures, weddings, and artistic projects.

- There is also the activity-specific platform that caters to a variety of industries but focuses on certain types of projects.

The most popular crowdfunding platform among Canadian firms is Kickstarter (US-based), both in terms of the number of campaigns that have reached their target and the funds collected. For example, 972 campaigns collected USD25.1 million on Kickstarter in 2015. A total of about 10,000 Canadian projects used Kickstarter in the last 6 years ${ }^{36}$. Indiegogo and FundRazr are also very popular websites for entrepreneurs in Canada. The Toronto-based company named TellSpec raised USD386,392 on Indiegogo to market their invention of a device that shows the allergens in the food you are eating. Another crowdfunding example in Ontario is how an Ottawa man named Frank Bouchard raised USD424,314 for his product called Wipebook, a notebook that acts as a whiteboard so that you

35 https://www.kickstarter.com/projects/597507018/pebble-e-paper-watch-for-iphone-and-android/description.

36 https://www.cbc.ca/news/canada/montreal/what-10-000-kickstarter-projects-reveal-about-canada-s-entrepreneurs-1. 4084372. 
can generate ideas from anywhere you want. This highly surpassed his original goal of USD4000 (Scarrow 2014). Crowdfunding platforms use social networks to spread their messages.

Regardless of which model you choose, there are two ways that the platforms typically get structured to allocate the funds. One of the structures is called the "all or nothing" model. This model has a set goal to raise and a funding period set. Once the funding period comes to an end, the project owner only receives the funds if the project's goal is met or surpassed. In the case that the goal is not met, the contributors are reimbursed their pledges or their credit cards are not charged for their donation amount. The other structure used is known as the "keep what you earn" model. This model allows the project owner to keep any and all funds raised during the funding period, regardless of if the initial goal was met or not. Crowdfunding platforms also have a variety of fee structures they use for the service they provide, namely, commission, subscription or a flat fee ${ }^{37}$.

Certain project categories are more popular than others in Canada. These include creative projects, arts, games and technology. Creative projects generally obtained a good success rate $(27 \%$ for art, $60.6 \%$ for theatre, $58 \%$ for comics, $51 \%$ for design, $50.9 \%$ for dance $)^{38}$. The success rate for video games is relatively low $(32.7 \%)$, but they are usually among the projects that raise the most funds in all. These patterns remained quite similar in 2015-2019.

In terms of crowdfunding regulation, it is noted that back in May 2015, the Globe and Mail newspapers came out with an article that outlined the six provinces that would be allowed to raise capital through crowdfunding websites ${ }^{39}$. Provincial securities regulators in British Columbia, Saskatchewan, Manitoba, Quebec, New Brunswick and Nova Scotia announced that companies in the early-stage would be allowed to issue shares to investors through crowdfunding websites. Ontario was also among the last of the six provinces but decided that they would not be participating in the new crowdfunding regime for start-ups. Instead, they would continue to develop a broader crowdfunding rule to cover both start-up companies as well as reporting issuers. In January 2016, the Ontario Securities Commission released the Companion Policy 45-108CP Crowdfunding, with a more detailed list of rules, regulations and explanations ${ }^{40}$. More recently, Alberta also adopted rules regulating crowdfunding activities ${ }^{41}$.

\section{References}

Adair, Philippe, and Mohamed Adaskou. 2015. Trade-off-theory vs. pecking order theory and the determinants of corporate leverage: Evidence from a panel data analysis upon French SMEs (2002-2010). Cogent Economics $\mathcal{E}$ Finance 3: 1-12.

Agrawal, Ajay, Christian Catalini, and Avi Goldfarb. 2010. The Geography of Crowdfunding. NBER Working Paper No. 16820. [CrossRef]

Ahlers, Gerrit, Douglas Cumming, Christina Günther, and Denis Schweizer. 2015. Signaling in Equity Crowdfunding. Entrepreneurship Theory and Practice 39: 955-80. [CrossRef]

Ahlstrom, David, Douglas Cumming, and Silvio Vismara. 2018. New methods of entrepreneurial firm financing: Fintech, crowdfunding and corporate governance implications. Corporate Governance: An International Review 26: 310-13. [CrossRef]

Amit, Raphael, James Brander, and Christoph Zott. 1997. Venture capital financing of entrepreneurship in Canada. In Financing Growth in Canada. Edited by P. Halpern. Calgary: University of Calgary Press.

37 http://crowdfunding.cmf-fmc.ca/facts_and_stats/types-of-crowdfunding-platforms.

38 https://www.cbc.ca/news/canada/montreal/what-10-000-kickstarter-projects-reveal-about-canada-s-entrepreneurs-1. 4084372.

39 http://www.theglobeandmail.com/report-on-business/six-provinces-approve-crowdfunding-ontario-to-developseparate-standards/article24444942/.

40 http://www.osc.gov.on.ca/en/SecuritiesLaw_cp_20160114_45-108_crowdfunding.htm.

41 See, e.g., https://ncfacanada.org/canada-update-alberta-updates-crowdfunding-regulations-but-where-does-canada-standin-the-national-harmonization-of-rules-what-about-fintech-development/. 
Baldwin, John, and Joanne Johnson. 1996. Business Strategies in Innovative and Non-Innovative Firms in Canada; Statistics Canada Working Paper 73; Victoria: Statistics Canada.

Beck, Thorsten, Asli Demirgüc-Kunt, and Vojislav Maksimovic. 2008. Financing patterns around the world: Are small firms different? Journal of Financial Economics 89: 467-87. [CrossRef]

Belitski, Maksim, Rosa Caiazza, and Erik Lehmann. 2019. Knowledge frontiers and boundaries in entrepreneurship research. Small Business Economics. [CrossRef]

Belleflamme, Paul, Thomas Lambert, and Armin Schwienbacher. 2014. Crowdfunding: Tapping the Right Crowd. Journal of Business Venturing: Entrepreneurship, Entrepreneurial Finance, Innovation and Regional Development 29: 585-609. [CrossRef]

Belleflamme, Paul, Nessrine Omrani, and Martin Peitz. 2015. The Economics of Crowdfunding Platforms. Information Economics and Policy 33: 11-28. [CrossRef]

Bellucci, Andrea, Ilario Favaretto, and Germana Giombini. 2014. Does Innovation Affect Credit Access? New Empirical Evidence from Italian Small Business Lending. IAW Discussion Papers 104.

Bhaumik, Sumon, Stuart Fraser, and Mike Wright. 2015. What Do We Know About Entrepreneurial Finance and Its Relationship with Growth? International Small Business Journal 33: 70-88.

Carpentier, Cécile, and Jean-Marc Suret. 2010. The Canadian Public Venture Capital Market. Strategic Change: Briefings in Entrepreneurial Finance 19: 303-23. [CrossRef]

Chemla, Gilles, and Katrin Tinn. 2019. Learning through Crowdfunding. Management Science 66: 1783-2290. [CrossRef]

Cumming, Douglas. 2005. Agency costs, institutions, learning, and taxation in venture capital contracting. Journal of Business Venturing 20: 573-622. [CrossRef]

Cumming, Douglas. 2006. Adverse Selection and Capital Structure: Evidence from Venture Capital. Entrepreneurship Theory and Practice 30: 155-84. [CrossRef]

Cumming, Shannon, and Thomas Hellmann. 2013. Non-Dilutive Funding Opportunities for Entrepreneurs in British Columbia, Canada. Project Report. Vancouver: University of British Columbia, Sauder School of Business.

Cumming, Douglas, and Lars Hornuf. 2018. The Economics of Crowdfunding Startups, Portals and Investor Behavior. New York: Palgrave Macmillan. [CrossRef]

Cumming, Douglas, and Sofia Johan. 2008. Information Asymmetries, Agency Costs and Venture Capital Exit Outcomes. Venture Capital, an International Journal of Entrepreneurial Finance 10: 197-231. [CrossRef]

Cumming, Douglas, and Jeffrey MacIntosh. 2003. Venture capital exits in Canada and the United States. University of Toronto Law Journal 53: 101-200. [CrossRef]

Cumming, Douglas, and Jeffrey MacIntosh. 2006. Crowding Out Private Equity: Canadian Evidence. Journal of Business Venturing 21: 569-609. [CrossRef]

Cumming, Douglas, Jeffrey MacIntosh, and Keith Godin. 2007. Crowding Out Private Equity: Canadian Evidence, Fraser Alert. Available online: https://pdfs.semanticscholar.org/bab0/190103eae482746f6c359872024cdf4f247b. pdf (accessed on 4 August 2020).

Cumming, Douglas, Marc Deloof, Sophie Manigart, and Mike Wright. 2019. New directions in entrepreneurial finance. Journal of Banking \& Finance 100: 252-60.

Damodaran, Aswath. 2003. Corporate Finance: Theory and Practice. New York: Wiley Series in Finance.

Das, Sanjiv. 2019. The future of FinTech. Financial Management 48: 981-1007. [CrossRef]

de Jong, Abe, Rezaul Kabir, and Thuy Thu Nguyen. 2008. Capital Structure around the World: The Roles of Firmand Country-Specific Determinants. Journal of Banking and Finance 32: 1954-69. [CrossRef]

Devereux, Michael, Giorgia Maffini, and Jing Xing. 2017. Corporate Tax Incentives and Capital Structure: New Evidence from UK Firm-Level Tax Returns. Available online: https://core.ac.uk/download/pdf/ 288289071.pdf (accessed on 4 August 2020).

Diamond, Douglas. 1991. Monitoring and Reputation: The Choice between Bank Loans and Directly Placed Debt. Journal of Political Economy 99: 689-721. [CrossRef]

Dingman, Shane. 2015. As Canadian Startups Grow, Local Venture Capital Funding Dries up. Technology Reporter. The Globe and Mail. Available online: https://www.theglobeandmail.com/report-on-business/small-business/ sb-money/as-canadian-startups-grow-local-venture-capital-funding-dries-up/article22972770/ (accessed on 4 August 2020).

Estrin, Saul, Daniel Gozman, and Susanna Khavul. 2018. The Evolution and Adoption of Equity Crowdfunding: Entrepreneur and Investor Entry into a New Market. Small Business Economics 51: 425-39. [CrossRef] 
Fairchild, Richard, Weixi Liu, and Yang Yao. 2017. An Entrepreneur's Choice of Crowd-Funding or Venture Capital Financing: The Effect of Entrepreneurial Overconfidence and CF-Investors' Passion. Working Paper. Available online: https://ssrn.com/abstract=2926980 (accessed on 4 August 2020). [CrossRef]

Frank, Murray, and Vidhan Goyal. 2003. Testing the Pecking Order Theory of Capital Structure. Journal of Financial Economics 67: 217-48. [CrossRef]

Funding Portal. 2013. Best Practices for Finding Your Optimal Sources of Funding. Available online: https:// fundingportal.com/blog/best-practices-for-finding-your-optimal-sources-of-funding/ (accessed on 1 June 2016).

Gallini, Nancy, and Aidan Hollis. 2019. To Sell or Scale Up: Canada's Patent Strategy in a Knowledge Economy. IRPP STUDY August 2019. No. 72. Available online: https://irpp.org/research-studies/to-sell-or-scale-up-canadaspatent-strategy-in-a-knowledge-economy/ (accessed on 4 August 2020).

Gill, Amarjit, and Neil Mathur. 2011. Factors that Influence Financial Leverage of Canadian Firms. Journal of Applied Finance \& Banking 1: 19-37.

Gilson, Ronald, and David Schizer. 2003. Venture capital structure: A tax explanation for convertible preferred stock. Harvard Law Review 116: 875-916. [CrossRef]

Graham, John R., and Campbell R. Harvey. 2001. The Theory and Practice of Corporate Finance: Evidence from the Field. Journal of Financial Economics 60: 187-243. [CrossRef]

Harris, Milton, and Artur Raviv. 1991. The Theory of Capital Structure. Journal of Finance 46: 297-356. [CrossRef]

Hashi, Iraj, and Valentin Toçi. 2010. Financing Constraints, Credit, Rationing, and Financing Obstacles: Evidence from Firm Level Data in South Eastern Europe. In Money, Banking and Financial Markets in Central and Eastern Europe. London: Palgrave Macmillan, pp. 62-97.

Hornuf, Lars, Matthias Schmitt, and Eliza Stenzhorn. 2020. Does a Local Bias Exist in Equity Crowdfunding? CESifo Working Paper Series 8154.

Huang, Winifred, Michele Meoli, and Silvio Vismara. 2019. The geography of initial coin offerings. Small Business Economics. [CrossRef]

Iacobucci, Edward, and Michael Trebilcock. 2012. The Role of Crown Corporations in the Canadian Economy: An Analytical Framework. SPP Research Paper No. 12-9. Available online: http://ssrn.com/abstract=2029931 (accessed on 4 August 2020).

Industry Canada. 2014. SME Research and Statistics, "Survey on Financing of Small and Medium Enterprises". Available online: http://www.ic.gc.ca/eic/site/061.nsf/eng/02997.html (accessed on 4 August 2020).

Jõeveer, Karin. 2013. What Do We Know about the Capital Structure of Small Firms? Small Business Economics 41: 479-501. [CrossRef]

Jude, Forbeneh, and Ntieche Adamou. 2018. Bank Loan Financing Decisions of Small and Medium-Sized Enterprises: The Significance of Owner/Managers' Behaviours. International Journal of Economics and Finance, Canadian Center of Science and Education 10: 231-41. [CrossRef]

Kaplan, Steven, and Per Strömberg. 2003. Financial contracting theory meets the real world: An empirical analysis of venture capital contracts. Review of Economic Studies 70: 281-315. [CrossRef]

Kashefi-Pour, Eilnaz, Meziane Lasfer, and Maria Carapeto. 2010. The Determinants of Capital Structure across Firms' Sizes: The U.K Main and AIM Markets Evidence. Available online: http://ssrn.com/abstract=1680892 (accessed on 4 August 2020).

Kazarian, Diane, and Bill McFarland. 2016. Canadian Banks 2016 Perspectives on the Canadian Banking Industry PWC Report. Available online: http://www.pwc.com/ca/en/industries/banking-capital-markets/publications/ canadian-banks.html (accessed on 1 June 2016).

Kelly, Dan. 2013. For many small businesses, the best bank isn't a bank at all. Financial Posts. June 3, 9:52 AM ET. Available online: http://business.financialpost.com/executive/c-suite/for-many-small-businesses-the-bestbank-isnt-a-bank-at-all (accessed on 4 August 2020).

King, Michael, and Eric Santor. 2008. Family Values: Ownership Structure, Performance, and Capital Structure of Canadian Firms. Journal of Banking \& Finance 32: 2423-32.

Klein, Linda Schmid, Thomas O'Brien, and Stephen Peters. 2002. Debt vs. Equity and Asymmetric Information: A Review. Financial Review 37: 317-49. [CrossRef]

Klyuev, Vladimir. 2008. Show Me the Money: Access to Finance for Small Borrowers in Canada. IMF Working Papers. pp. 1-29. Available online: http://ssrn.com/abstract=1089688 (accessed on 4 August 2020).

Kraus, Alan, and Robert Litzenberger. 1973. A State-preference Model of Optimal Financial Leverage. Journal of Finance 28: 911-22. [CrossRef] 
Lee, Neil, Hiba Sameen, and Marc Cowling. 2015. Access to finance for innovative SMEs since the financial crisis. Research Policy 44: 370-80. [CrossRef]

Leland, Hayne, and David Pyle. 1977. Information asymmetries, financial structure, and financial intermediation. Journal of Finance 32: 371-87. [CrossRef]

Lerner, Josh. 2009. Boulevard of Broken Dreams: Why Public Efforts to Boost Entrepreneurship and Venture Capital Have Failed - And What to Do About It. Princeton: Princeton University Press.

MacIntosh, Jeffrey. 2012. Tantalus Unbound: Government Policy and Innovation in Canada. SPP Research Papers. Calgary: University of Calgary, vol. 5.

Mann, William. 2018. Creditor Rights and Innovation: Evidence from Patent Collateral. Journal of Financial Economics 130: 25-47. [CrossRef]

Miglo, Anton. 2011. Trade-off, Pecking Order, Signaling and Market Timing Models. In Capital Structure and Corpo-Rate Financing Decisions: Theory, Evidence, and Practice. Edited by H. K. Baker and G. S. Martin. New York: Wiley, chp. 10. pp. 171-90.

Miglo, Anton. 2016. Capital Structure in the Modern World. New York: Springer/Palgrave MacMillan.

Miglo, Anton. 2020. Theories of Financing for Entrepreneurial Firms: A Review. Unpublished working paper.

Miglo, Anton, and Victor Miglo. 2019. Market Imperfections and Crowdfunding. Small Business Economics Journal 53: 51-79. [CrossRef]

Mochkabadi, Kazem, and Christine Volkmann. 2020. Equity Crowdfunding: A Systematic Review of the Literature. Small Business Economics 54: 75-118. [CrossRef]

Modigliani, Franco, and Merton Miller. 1963. Corporate income taxes and the cost of capital: A correction. American Economic Review 53: 433-43.

Moritz, Alexandra, and Jörn Hendrich Block. 2014. Crowdfunding: A Literature Review and Research Directions. Available online: http://ssrn.com/abstract=2554444 (accessed on 4 August 2020). [CrossRef]

Nicholson, P. 2009. Innovation and Business Strategy: Why Canada Falls Short. Council of Canadian Academies. Available online: file://C:/Users/ID125945/Downloads/Innovation_and_Business_Strategy_Why_Canada_ Falls_\%20(1).pdf (accessed on 4 August 2020).

OECD (Organisation for Economic Co-operation and Development). 2012. Financing SMEs and Entrepreneurs 2012 An OECD Scoreboard. Available online: http://www.oecd-ilibrary.org/industry-and-services/financingsmes-and-entrepreneurship_9789264166769-en (accessed on 1 January 2015).

Ozkan, A. 1996. Costs of Financial Distress and Capital Structure of Firms. Ph.D. thesis, University of York, York.

Rainey, McKenzie, Sheen Sagalongos, James Tansey, and Varun Srivatsan. 2017. Equity Crowdfunding: A New Model for Financing Start-Ups and Small Businesses. Available online: https://static1.squarespace.com/static/ 598b47ff6a49631e85d75e53/t/5a20764cc8302566a3a23863/1512076878794/SauderS3i_Equity_Crowdfunding_ FINAL.pdf (accessed on 4 August 2020).

Robb, Alicia, and David Robinson. 2012. The capital structure decisions of new firms. The Review of Financial Studies 1: 1-27.

Saltzman, Aaron. 2015. Bank Fees for Small Business: Where's the Value for Money? CBC News. April 28, 5:00 AM ET Last Updated: April 28, 4:00 PM ET. Available online: http://www.cbc.ca/news/business/bank-feesfor-small-business-where-s-the-value-for-money-1.3045924 (accessed on 4 August 2020).

Sandler, Daniel. 2004. Venture Capital and Tax Incentives: A Comparative Study of Canada and the United States. Toronto: Canadian Tax Foundation, ISSN 0008-512X.

Scarrow, Katherine. 2014. Ten of Canada's Most Successful Crowdfunding Campaigns. Retrieved October 21. Available online: http://www.theglobeandmail.com/report-on-business/small-business/sb-money/businessfunding/photos-the-years-top-crowdfunders/article16111603/ (accessed on 4 August 2020).

Schmidt, Holger, Roger Mason, Juan-Pierré Bruwer, and Jonathan Aspeling. 2017. Access to finance problems for small retail businesses in South Africa: Comparative views from finance seekers (retailers) and finance providers (banks). Banks and Bank Systems 12: 20-30. [CrossRef]

Schwienbacher, Armin. 2018. Entrepreneurial Risk-taking in Crowdfunding Campaigns. Small Business Economics 51: 843-59. [CrossRef]

Schwienbacher, Armin, and Benjamin Larralde. 2012. Alternative Types of Entrepreneurial Finance. In The Oxford Handbook of Entrepreneurial Finance. Edited by Douglas Cumming. New York: Oxford University Press.

Solesvik, Marina, Paul Westhead, and Harry Matlay. 2014. Cultural factors and entrepreneurial intention: The role of entrepreneurship education. Education + Training 56: 680-96. [CrossRef] 
Stiglitz, Joseph, and Andrew Weiss. 1981. Credit rationing in markets with imperfect information. American Economic Review 73: 93-409.

Strausz, Roland. 2017. Crowdfunding, Demand Uncertainty, and Moral Hazard-A Mechanism Design Approach. American Economic Review 107: 1430-76. [CrossRef]

Suret, Jean-Marc. 2008. Labour-Sponsored Venture Capital Funds: Time for a Reassessment. Montreal: Montreal Economic Institute, Available online: https://www.iedm.org/322-labour-sponsored-venture-capital-fundstime-for-a-reassessment/ (accessed on 4 August 2020).

Taylor, James. 2012. Non-Dilutive Financing for Biotech Startups. Tradesecrets. Available online: http://blogs.nature. com/tradesecrets/2012/10/09/non-dilutivefinancing-for-biotech-startups (accessed on 1 July 2013).

Vaiiancourt, François. 1998. Labour-sponsored venture capital funds in Canada: Institutional aspects, tax expenditures and employment creation. In Financing Growth in Canada. Edited by P. Halpern. Calgary: University of Calgary Press, chp. 13.

(C) 2020 by the author. Licensee MDPI, Basel, Switzerland. This article is an open access article distributed under the terms and conditions of the Creative Commons Attribution (CC BY) license (http://creativecommons.org/licenses/by/4.0/). 